\title{
Genome Stability by DNA Polymerase $\beta$ in Neural Progenitors Contributes to Neuronal Differentiation in Cortical Development
}

\author{
Kohei Onishi, ${ }^{1}$ Akiko Uyeda, ${ }^{1}$ Mitsuhiro Shida, ${ }^{1}$ Teruyoshi Hirayama, ${ }^{1,2}$ Takeshi Yagi, ${ }^{1,2}$ Nobuhiko Yamamoto, ${ }^{1}$ \\ and $\odot$ Noriyuki Sugo ${ }^{1}$ \\ ${ }^{1}$ Graduate School of Frontier Biosciences, Osaka University, Osaka, 565-0871, Japan, and 2AMED-CREST, Japan Agency for Medical Research and \\ Development (AMED), 1-3 Yamadaoka, Suita, Osaka, 565-0871, Japan
}

DNA repair is crucial for genome stability in the developing cortex, as somatic de novo mutations cause neurological disorders. However, how DNA repair contributes to neuronal development is largely unknown. To address this issue, we studied the spatiotemporal roles of DNA polymerase $\beta(\operatorname{Pol} \beta)$, a key enzyme in DNA base excision repair pathway, in the developing cortex using distinct forebrain-specific conditional knock-out mice, Emxl-Cre/Pol $\beta^{f l / f l}$ and Nex-Cre/Pol $\beta^{f l f l}$ mice. Pol $\beta$ expression was absent in both neural progenitors and postmitotic neurons in Emxl-Cre/Pol $\beta^{f l / f l}$ mice, whereas only postmitotic neurons lacked Pol $\beta$ expression in Nex-Cre/Pol ${ }^{f l / f l}$ mice. We found that DNA double-strand breaks (DSBs) were frequently detected during replication in cortical progenitors of $E m \times 1$-Cre/Pol $\beta^{f l / f l}$ mice. Increased DSBs remained in postmitotic cells, which resulted in p53-mediated neuronal apoptosis. This neuronal apoptosis caused thinning of the cortical plate, although laminar structure was normal. In addition, accumulated DSBs also affected growth of corticofugal axons but not commissural axons. These phenotypes were not observed in Nex-Cre/Pol $\beta^{f l f l}$ mice. Moreover, cultured Pol $\beta$-deficient neural progenitors exhibited higher sensitivity to the base-damaging agent methylmethanesulfonate, resulting in enhanced DSB formation. Similar damage was found by vitamin C treatment, which induces TET1-mediated DNA demethylation via 5-hydroxymethylcytosine. Together, genome stability mediated by Pol $\beta$-dependent base excision repair is crucial for the competence of neural progenitors, thereby contributing to neuronal differentiation in cortical development.

Key words: cortical development; DNA demethylation; DNA double-strand break; DNA repair; neuronal apoptosis; neuronal differentiation

\section{Significance Statement}

DNA repair is crucial for development of the nervous system. However, how DNA polymerase $\beta(\operatorname{Pol} \beta)$-dependent DNA base excision repair pathway contributes to the process is still unknown. We found that loss of $\mathrm{Pol} \beta$ in cortical progenitors rather than postmitotic neurons led to catastrophic DNA double-strand breaks (DSBs) during replication and p53-mediated neuronal apoptosis, which resulted in thinning of the cortical plate. The DSBs also affected corticofugal axon growth in surviving neurons. Moreover, induction of base damage and DNA demethylation intermediates in the genome increased DSBs in cultured Pol $\beta$ deficient neural progenitors. Thus, genome stability by $\mathrm{Pol} \beta$-dependent base excision repair in neural progenitors is required for the viability and differentiation of daughter neurons in the developing nervous system.

\section{Introduction}

Cortical developmental disorders, such as autism spectrum disorders, are attributable to multiple gene mutations (Poduri et al.,

Received Feb. 26, 2017; revised July 6, 2017; accepted July 27, 2017.

Author contributions: T.Y., N.Y., and N.S. designed research; K.O., A.U., M.S., T.H., and N.S. performed research; K.O., A.U., M.S., T.H., and N.S. analyzed data; K.O., T.Y., N.Y., and N.S. wrote the paper.

This work was supported by MEXT KAKENHI on Innovative Areas Mesoscopic Neurocircuitry 23115102 and Dynamic Regulation of Brain Function by Scrap and Build System 16 H06460 to N.Y., Cross Talk Between Moving Cells and Microenvironment as a Basis of Emerging Order in Multicellular System 23111516, Grant 20200009 to N.S., Japan Society for the Promotion of Science KAKENHI Grants 23700447, 15K14350, and 17 K07109 to N.S. and Grants 20300110 and 23300118 to N.Y., and AMED-Core Research for Evolutional Science and Technology to T.Y. We thank
2013). Recent whole-genome sequence technology revealed that CNS neurons have somatic de novo mutations involving single nucleotide variation, copy number variation, and retrotranspo-

Drs. T. Iwasato and S. Itohara for Emx1-Cre mice; K.A. Nave for the Nex-Cre mice; K. Rajewsky for Pol $\beta$ flox mice; Drs S. Toyoda, K. Takiguchi-Hayashi, and N. Adachi for helpful discussion; and Dr. I. Smith and H. Gabriel for critical reading of the manuscript.

The authors declare no competing financial interests.

Correspondence should be addressed to Dr. Noriyuki Sugo, Graduate School of Frontier Biosciences, Osaka University Yamadaoka 1-3, Suita, 0saka 565-0871, Japan. E-mail: sugo@fbs.osaka-u.ac.jp.

DOI:10.1523/JNEUROSCI.0665-17.2017

Copyright $\odot 2017$ the authors $\quad 0270-6474 / 17 / 378444-15 \$ 15.00 / 0$ 
sition (Poduri et al., 2012; McConnell et al., 2013; Bundo et al., 2014). Further, increasing evidence suggests that even a very small number of cortical neurons with mutations can disrupt the function of cortical circuits (Poduri et al., 2013). Thus, genome stability is essential for normal cortical development and function.

DNA repair is necessary to maintain genome stability. Human genetic diseases caused by DNA repair defects include immune dysfunction and cancer predisposition (Lindahl and Wood, 1999). In the nervous system, DNA repair deficiency can result in microcephaly, ataxia, mental retardation, and neurodegeneration (Caldecott, 2008; McKinnon, 2013). It is likely that these disorders are attributable to neuronal cells with extensive DNA damage; indeed, mice deficient in several DNA repair enzymes exhibit neuronal apoptosis and structural abnormalities in the developing brain (Gao et al., 1998; Deans et al., 2000; Gu et al., 2000; Sugo et al., 2000). An intriguing question is how these DNA repair enzymes function in normal brain development.

DNA polymerase $\beta(\operatorname{Pol} \beta)$, a core component of the base excision repair (BER) pathway, has been shown to be involved in development of the nervous system rather than that of other organs (Sobol et al., 1996; Sugo et al., 2000; Wilson et al., 2000; Niimi et al., 2005). The most characteristic aspect has been shown in the developing cortex of $\operatorname{Pol} \beta$-deficient mice $\left(\right.$ Pol $\left.^{-/-}\right)$; extensive apoptosis occurs in the intermediate zone (IZ) and cortical plate (CP) rather than the ventricular zone (VZ) (Sugo et al., 2000, 2004). Because it is known that $\mathrm{Pol} \beta$-dependent BER can remove spontaneous apurinic/apyrimidic sites and reactive oxygen species-induced oxidative DNA base damage in aerobic cells (Lindahl, 1993; Sobol et al., 1996), such DNA damage likely increases susceptibility to genome instability in $\mathrm{Pol} \beta$-deficient cortical cells. In addition to the accidental and pathological damage, physiological damage may also be repaired by the $\operatorname{Pol} \beta$-dependent BER machinery. Indeed, the BER pathway is involved in active DNA demethylation process, which is necessary for epigenetic regulation of gene expression (Bhutani et al., 2011). However, how Pol $\beta$-dependent BER contributes to the development of the nervous system remains unknown.

In the present study, we investigated the roles of $\operatorname{Pol} \beta$ in the developing cortex using forebrain-specific conditional knockout mice. We found that $\operatorname{Pol} \beta$ deficiency led to increased DNA double-strand breaks (DSBs) during $\mathrm{S}$ phase in neural progenitors, and subsequently p53-mediated neuronal apoptosis. The DSBs remained unrepaired in surviving postmitotic neurons, causing corticofugal axon growth defects. Induction of pathological base damage and epigenetic base modification markedly enhanced DSB formation in cultured $\mathrm{Pol} \beta$-deficient neural progenitors. These findings demonstrate that genome stability mediated by $\mathrm{Pol} \beta$-dependent BER suppresses DSB formation in neural progenitors and underlies neuronal differentiation in cortical development.

\section{Materials and Methods}

Mice. To generate Pol $\beta^{\text {del/del }}$ mice, Pol $\beta^{f l f l}$ mice (Gu et al., 1994) were crossed with Sycp1-Cre mice (Noguchi et al., 2009), and then Sycp1-Crel Pol $\beta^{f l /+}$ male mice were crossed with C57BL/6J background female mice. p53-deficient mice (Tsukada et al., 1993) were also crossed with Pol $^{\text {del//+}}$ mice. To generate Emxl-Cre/Pol $\beta^{f l f l}$ mice and Nex-Cre/Pol $f^{f l / f l}$ mice, we crossed Pol $\beta^{f l f l}$ mice with Emx1-Cre (Iwasato et al., 2000) and Nex-Cre mice (Goebbels et al., 2006), respectively. Noon of the day on which the vaginal plug was detected was designated embryonic day 0.5 (E0.5). All experiments were conducted under the guidelines for laboratory animals of the Graduate School of Frontier Biosciences, Osaka University. The protocol was approved by the Animal Care and Use
Committee of the Graduate School of Frontier Biosciences, Osaka University.

In situ hybridization. cDNA fragment encoding Pol $\beta$ (NM_011130.2, nucleotides 31-1079) and Pax6 (NM_013627.1, nucleotides 161-1559) was subcloned into pGEM-T Easy vector (Promega). The preparation of RNA probes and in situ hybridization were performed as described previously (Zhong et al., 2004).

In utero electroporation. pCAGGS-EGFP plasmid DNA was purified with the PureLink HiPure Plasmid Maxiprep Kit (Invitrogen), then dissolved in PBS. In utero electroporation was performed on E13.5 embryos (Fukuchi-Shimogori and Grove, 2001). Pregnant mice were deeply anesthetized with isoflurane (Wako) by using inhalation anesthesia equipment (KN-1071-1, Natume). A total of $1 \mu \mathrm{g}$ of plasmid solution was injected to the lateral ventricle with a glass micropipette connected to an injector (IM-30, Narishige). Electric pulses were delivered with tweezers electrodes (LF650P1, BEX) connected to an electroporator (CUY21, $\mathrm{BEX}$ ). Five $35 \mathrm{~V}$ pulses of $50 \mathrm{~ms}$ duration were applied at intervals of $100 \mathrm{~ms}$.

Immunostaining. The brains were fixed with 2 or $4 \%$ PFA in $0.1 \mathrm{M}$ sodium phosphate buffer, $\mathrm{pH} 7.4$, equilibrated with $25 \%$ sucrose-PBS, frozen in OCT compound (Sakura Finetech), and cut into 4, 10, or $20 \mu \mathrm{m}$ sections using a cryostat (CM1850, Leica). The sections were permeabilized and blocked for $1 \mathrm{~h}$ at room temperature in buffer $\mathrm{G}(0.1 \%$ or $1.0 \%$ Triton X-100, 5\% normal goat serum, Vector Laboratories in PBS) or buffer D $(0.1 \%$ or $1.0 \%$ Triton X-100, $2 \%$ normal donkey serum, Jackson ImmunoResearch Laboratories in PBS). The sections were incubated overnight at $4^{\circ} \mathrm{C}$ with the following antibodies in buffer $\mathrm{G}$ or buffer $\mathrm{D}$ : rabbit polyclonal anticleaved caspase-3 (Asp175) (9661S, Cell Signaling Technology) at 1:250, mouse monoclonal anti-neuron-specific $\beta$-III tubulin (Tuj1) (MAB1195, R\&D Systems) at 1:1000, goat polyclonal antiNurr1 (AF2156, R\&D Systems) at 1:50, rabbit polyclonal anti-Tbr1 (ab31940, Abcam) at 1:500, rat monoclonal anti-Ctip2 (ab18465, Abcam) at 1:800, rabbit polyclonal anti-CDP (Cux1) (sc-13024, Santa Cruz Biotechnology) at 1:200, rat monoclonal anti-GFP (04404-84, Nacalai Tesque) at 1:1000, goat polyclonal anti-Contaction-2 (TAG-1) (AF4439, $\mathrm{R} \& \mathrm{D}$ Systems) at 1:200, rabbit polyclonal anti-histone $\mathrm{H} 2 \mathrm{AX}$ phosphor Ser139 ( $\gamma \mathrm{H} 2 \mathrm{AX})$ (39117, Active Motif) at 1:200, rabbit monoclonal antiKi67 (RM-9106-S0, Thermo Scientific) at 1:200, or rabbit polyclonal anti-53BP1 (GTX102595, GeneTex) at 1:100. For Pol $\beta$ immunostaining, the sections were fixed with 2\% PFA in PBS for 5 min at room temperature, then washed with PBS for 10 min three times. The sections were treated with $1.0 \%$ SDS in PBS for $10 \mathrm{~min}$ at room temperature, then washed with PBS for 10 min three times. The sections were incubated with $10 \%$ normal goat serum in PBS for $1 \mathrm{~h}$ at room temperature, then incubated overnight at $4^{\circ} \mathrm{C}$ with rabbit polyclonal anti-DNA polymerase $\beta$ antibody (ab26343, Abcam) diluted in Can Get Signal immunostain solution A (Toyobo) at 1:500. Primary antibodies were detected by incubation with Alexa488-conjugated antimouse IgG (A-11029, Invitrogen), Alexa488-conjugated antirabbit IgG (A-11034, Invitrogen), Alexa488conjugated antirat IgG (A-11006, Invitrogen), Cy3-conjugated antimouse IgG (AP192C, Millipore), Cy3-conjugated antirabbit IgG (AP182C, Millipore), Cy3-conjugated antirat IgG (AP136C, Millipore), or Cy3-conjugated antigoat IgG (705-165-147, Jackson ImmunoResearch Laboratories), in all cases at 1:400 in buffer $G$ or buffer $D$ for $2 \mathrm{~h}$ at room temperature. The sections were washed with PBS for 10 min three times. Nuclei were stained with $0.1 \%$ DAPI (Sigma) in a mounting medium containing $50 \%$ glycerol and 2.3\% 1,4-diazobicyclo[2.2.2] octane (Sigma) in $50 \mathrm{~mm}$ Tris- $\mathrm{HCl}, \mathrm{pH}$ 8.0.

Cultured cells were fixed with 4\% PFA in PBS for 10 min at room temperature. The cells were permeabilized and blocked for $1 \mathrm{~h}$ in buffer $\mathrm{G}$ at room temperature. They were incubated with rabbit polyclonal anti$\gamma \mathrm{H} 2 \mathrm{AX}$ antibody at 1:200, rabbit polyclonal anti-53BP1 antibody at 1:100, or mouse monoclonal anti-nestin antibody (MAB353, Millipore) at 1:200 in buffer $\mathrm{G}$ overnight at $4^{\circ} \mathrm{C}$. Primary antibodies were visualized by incubation with Alexa488-conjugated antimouse IgG, Alexa488-conjugated antirabbit IgG, and Cy3-conjugated antimouse IgG at 1:400 in buffer $\mathrm{G}$ for $2 \mathrm{~h}$ at room temperature. The cells were mounted with DAPI-containing medium as above.

5-Ethynyl-2'-deoxyuridine (EdU) labeling. Pregnant mice were injected intraperitoneally with $150 \mu \mathrm{l}$ of EdU $(2.5 \mathrm{mg} / \mathrm{ml}$ in PBS, Invitro- 
gen), and embryos were harvested at $30 \mathrm{~min}$ after the injection or at E18.5. EdU was visualized using a Click-iT EdU AlexaFluor-555 imaging kit (Invitrogen) according to the manufacturer's recommendations.

Quantitative RT-PCR. Total RNA was extracted from E14.5 Pol ${ }^{f l / f l}$ and Emxl-Cre/ $P o l \beta^{f l f l}$ cortices using RNeasy Plus Mini Kit (QIAGEN) following the manufacturer's procedure. cDNA synthesis was performed using Transcriptor First Strand cDNA Synthesis Kit (Roche). Quantitative RT-PCR was performed with Universal ProbeLibrary (UPL, Roche). Specific probes and intron-spanning primer pairs were designed using Universal ProbeLibrary Assay Design Center (https://qpcr. probefinder.com/organism.jsp). The following probes and primer pairs were used in each gene. Gap43, UPL probe $63,5^{\prime}-$ cggagactgcagaaagcag- $3^{\prime}$ and $5^{\prime}$-ggtttggcttcgtcta cagc- $3^{\prime}$; Apc, UPL probe $70,5^{\prime}$-gtgcgccagctttta cagt- $3^{\prime}$ and $5^{\prime}$-catgcctgctctgagatgac- $3^{\prime}$; Tubb6, UPL probe 55, 5'-ctacgtgggcgactcagc- $3^{\prime}$ and $5^{\prime}$ agccctgggtacgtacttctt- $3^{\prime}$; and Rplp1, UPL probe $67,5^{\prime}$-ttctggcctggcttgttt- $3^{\prime}$ and $5^{\prime}$-atggagcagcacc accag- $3^{\prime}$. GAPD gene was used as an endogenous control (UPL Mouse GAPD Gene Assay, Roche).

Cell culture. Pregnant mice were deeply anesthetized with pentobarbital $(50 \mathrm{mg} / \mathrm{kg}$, i.p.). E14.5 cortices were collected from the embryos in ice-cold Hanks' solution and then minced with fine scissors in PBS. The minced tissues were incubated with $0.125 \%$ trypsin and $0.02 \%$ EDTA in PBS for $5 \mathrm{~min}$ at $37^{\circ} \mathrm{C}$, and then dissociated by pipetting. After centrifugation, the cells were resuspended in a mixture of DMEM and F12 (Invitrogen), 10\% FBS (Hyclone), 10 $\mathrm{ng} / \mathrm{ml}$ mouse FGF (Peprotech), and $20 \mathrm{ng} / \mathrm{ml}$ mouse EGF (Peprotech). A suspension containing 1.5-2.0 $\times 10^{5}$ cells was plated with culture medium on a $12 \mathrm{~mm}$ microcoverglass (Matsunami) in a Nunc 4-well dish (Thermo Scientific); alternatively, 6.5-7.5 $\times 10^{5}$ cells were plated on $35 \mathrm{~mm}$ cell culture dishes (Falcon) coated with $0.1 \mathrm{mg} / \mathrm{ml}$ poly-L-ornithine (Sigma). The cultures were maintained at $37^{\circ} \mathrm{C}$ in an environment of $5 \% \mathrm{CO}_{2}$ and humidified $95 \%$ air.

To label DNA with EdU, the cells were incubated with culture medium containing $20 \mu \mathrm{M}$ EdU (Invitrogen) for $15 \mathrm{~min}$. To induce base damage, the cells were treated with culture medium containing $1 \mathrm{~mm}$ methylmethanesulfonate (MMS) (Sigma) for $1 \mathrm{~h}$, then fixed for $10 \mathrm{~min}$.

To induce DNA demethylation, the cells were incubated with culture medium containing 100 $\mu \mathrm{g} / \mathrm{ml} \mathrm{L}$-ascorbic acid 2-phosphate (vitamin C, Sigma) for $24 \mathrm{~h}$, and then fixed for $10 \mathrm{~min}$.

Immunoblot analysis. Genomic DNA was extracted using DNeasy Blood and Tissue kit (QIAGEN) or MagExtractor-Genome-kit (Toyobo). Isolated DNA was denatured in $0.1 \mathrm{M} \mathrm{NaOH}$ for $5 \mathrm{~min}$ at $95^{\circ} \mathrm{C}$ and then chilled on ice. For immunoblot analysis of 5-methylcytosine $(5 \mathrm{mC})$, serially diluted DNA samples $(200 \mu \mathrm{l})$ were loaded on a positively charged nylon membrane (Millipore) using Bio-Dot SF Microfiltration Apparatus (BioRad). For immunoblot analysis of 5-hydroxymethylcytosine $(5 \mathrm{hmC})$, aliquots $(1 \mu \mathrm{l})$ of serially diluted DNA samples were spotted on a positively charged nylon membrane (Millipore). The blotted membrane

B
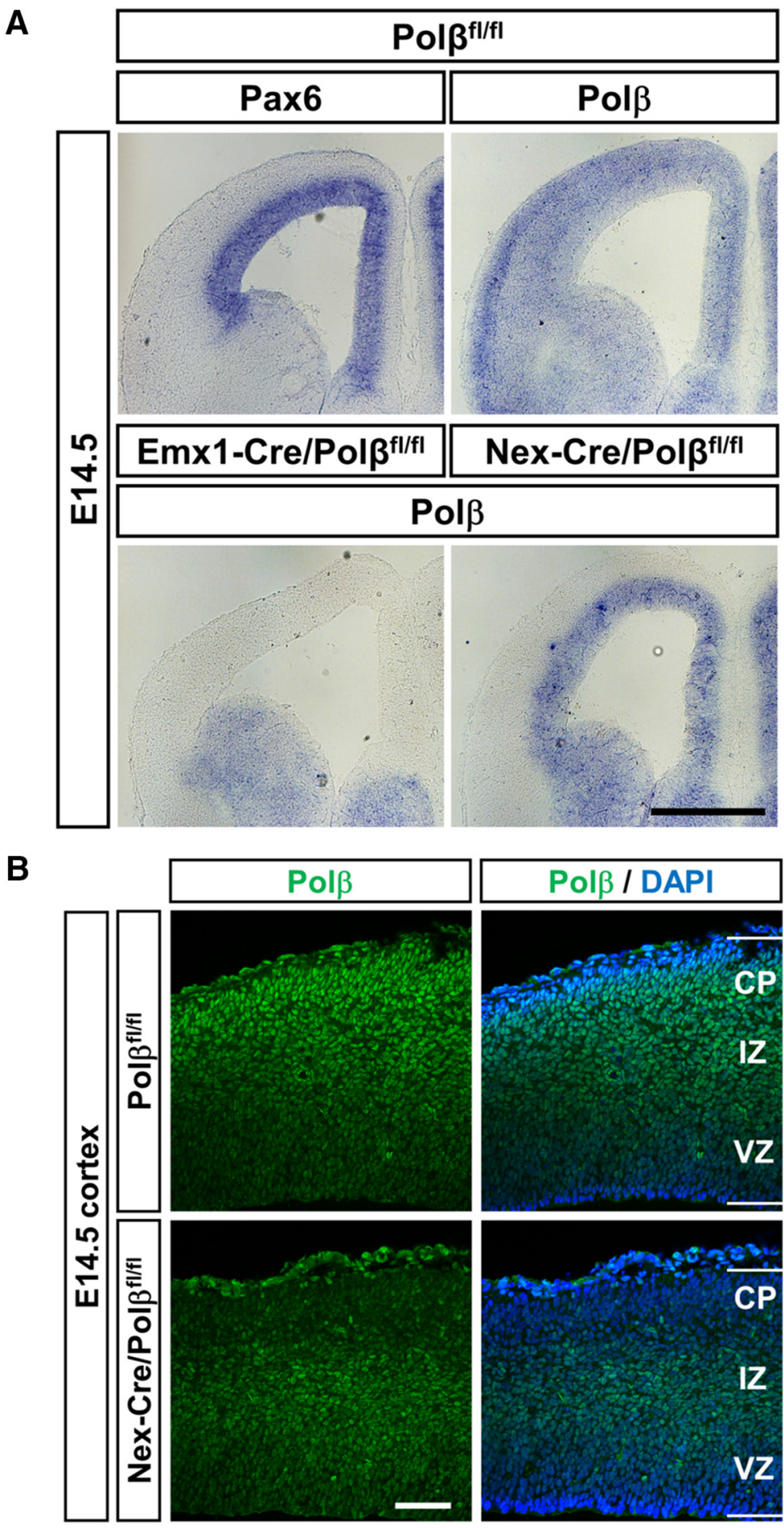

Figure 1. Forebrain-specific CRE-mediated recombination occurs in Pol $\beta$ conditional mutant mice. $\boldsymbol{A}$, In situ hybridization of Pax6 and Pol $\beta$ was performed in E14.5 Pol $\beta^{f / f l}, E m x 1-C r e / P o l \beta^{f l / f l}$, and Nex-Cre/Pol $\beta^{f / / f l}$ forebrain. Scale bar, $500 \mu \mathrm{m}$. $\boldsymbol{B}$, Immunohistochemistry was performed with anti-Pol $\beta$ antibody in E14.5 wild-type and Nex-Cre/Pol $\beta^{\text {fl/fl }}$ cortex. Nuclei were stained with DAPI. Scale bar, $100 \mu \mathrm{m}$.

was air-dried and UV cross-linked using a CL-1000 Ultraviolet Crosslinker. The membrane was washed with Tris-buffered saline containing $0.1 \%$ Tween 20 (TBS-T) for $30 \mathrm{~min}$ and then blocked in TBS-T containing 5\% skim milk (Cell Signaling Technology) for $1 \mathrm{~h}$ at room temperature. The membrane was incubated with mouse monoclonal anti-5mC antibody (39649, Active Motif) at 1:2000 or rabbit polyclonal anti-5hmC antibody (39769, Active Motif) at 1:5000 in TBS-T containing 5\% skim milk overnight at $4^{\circ} \mathrm{C}$. The membrane was washed with TBS-T for $10 \mathrm{~min}$ three times and then incubated with antimouse IgG HRP conjugate (115- 
Table 1. Genotyping of $P$ ol $\beta^{d e l /+}$ intercrosses

\begin{tabular}{lllll}
\hline & \multicolumn{2}{l}{$P$ ol $\beta^{\text {del/+}} \times$ Pol $\beta^{\text {del/+ }}$} & Total no. \\
\cline { 2 - 5 } Stage & Pol $\beta^{+/+}$ & $P o l \beta^{\text {del/+ }}$ & $P o l \beta^{\text {del/del }}$ & (no. litters) \\
\hline E14.5 & 16 & 28 & 11 & $55(9)$ \\
Weaned & 35 & 78 & 0 & $113(23)$ \\
\hline
\end{tabular}

035-146, Jackson ImmunoResearch Laboratories) or -rabbit IgG HRP conjugate (711-035-152, Jackson ImmunoResearch Laboratories) at $1: 20,000$ in TBS-T containing 5\% skim milk for $2 \mathrm{~h}$ at room temperature. The membrane was washed with TBS-T for $10 \mathrm{~min}$ three times and visualized by chemiluminescence with ECL Select Western Blotting Detection Reagent (GE Healthcare), and images were captured with an LAS-3000 UV mini (Fujifilm).

Image analysis. Digital images were obtained by confocal microscopy (ECLIPSE FN with EZ-C1; Nikon) with $10 \times / 0.3,20 \times / 0.75,40 \times / 0.95$, and $100 \times / 1.40$ objective lenses (Nikon). The images were imported into Photoshop 6.0 (Adobe Systems) and ImageJ to adjust brightness and contrast.

For the quantitative analysis of $\operatorname{Pol} \beta$ protein levels, fluorescence intensities of $\mathrm{Pol} \beta$ in the nucleus were quantified using ImageJ. The position of the nucleus was judged by DAPI staining. The fluorescence intensities of $\operatorname{Pol} \beta$ in the CP neurons of Emxl-Cre/Pol $\beta^{f l / f l}$ mice were measured as background intensity. The average intensities were calculated from 10 cells in a section. The ratio was calculated from three independent experiments from two embryonic mice, respectively.

Experimental design and statistical analysis. Mice in both sexes were used for all experiments. In statistical analysis, the analyzed number of samples was described in each experiment. Significant differences were determined with Student's $t$ test or Mann-Whitney $U$ test. All statistical values are presented as mean value $\pm \mathrm{SD}$ or mean value \pm SEM. All data were analyzed using Excel 2013 (Microsoft).

\section{Results}

$\operatorname{Pol} \beta$ deficiency in neural progenitors induces neuronal apoptosis in the developing cortex

To dissect $\operatorname{Pol} \beta$ functions in neural progenitors and postmitotic neurons, Pol $\beta^{\text {flflfl }}$ mice (Gu et al., 1994) were crossed with Cre driver lines Emxl-Cre and Nex-Cre. Emx1-Cre-mediated recombination occurs in neural progenitors restricted to the dorsal telencephalon (Iwasato et al., 2000), whereas Nex-Cre-mediated recombination occurs in postmitotic excitatory neurons (Goebbels et al., 2006). In addition, to generate mice lacking $\operatorname{Pol} \beta$ in the whole-body (Pol $\left.\beta^{\text {del/del }}\right)$, which correspond to conventional Pol $\beta^{-/-}$knock-out mice, Pol $\beta^{f l f l}$ mice were crossed with mice from a testis-specific Cre driver line, Sycp1-Cre (Noguchi et al., 2009). To confirm CRE-mediated recombination of the floxed $\operatorname{Pol} \beta$ allele, in situ hybridization were performed on these mutant cortices (Fig. 1A). As expected, $\operatorname{Pol} \beta$ expression disappeared in both neural progenitors in the VZ and postmitotic neurons in the $\mathrm{CP}$ of Emx1-Cre/Pol ${ }^{f l / l l}$ mice, whereas only postmitotic neurons lacked expression of $\mathrm{Pol} \beta$ in Nex-Cre/Pol/ $\beta^{\text {flflfl }}$ mice. Consistent with this result, immunohistochemistry further showed that $\operatorname{Pol} \beta$ signal in Nex-Cre/Pol $\beta^{f l / f l}$ mice was almost absent in CP cells (the signal intensity in CP cells was $14 \pm 3 \%$ of that in Pol $\beta^{f / f l}$ mice) (Fig. 1B). Thus, these mutant mice allowed us to study the spatiotemporal role of $\mathrm{Pol} \beta$ in the developing cortex, focusing on proliferative neural progenitors and postmitotic neurons.

Consistent with a previous result (Sugo et al., 2000), Pol $\beta^{\text {del/del }}$ mice died after birth (Table 1). Meanwhile, both Emx1-Cre/ $\mathrm{Pol}^{f l / f l}$ and Nex-Cre/Pol $\beta^{f l f l}$ mice were obtained at the expected Mendelian ratios at both E14.5 and the weaning stage (Tables 2, 3 ), indicating that the dorsal telencephalon-specific $\operatorname{Pol} \beta$ deficiency does not lead to lethality. According to the previous study (Sugo et al., 2000), we examined apoptosis in the developing
Table 2. Genotyping of Emx1-Cre/Pol $\beta^{f l / f l}$ mice

\begin{tabular}{|c|c|c|c|}
\hline \multirow[b]{2}{*}{ Stage } & \multicolumn{2}{|c|}{$P_{0} / \beta^{f / f l} \times E m \times 1^{\text {(rel } /+} / P_{0} l \beta^{f / f I}$} & \multirow{2}{*}{$\begin{array}{l}\text { Total no. } \\
\text { (no. of litters) }\end{array}$} \\
\hline & $\overline{P o l} \beta^{f / f f}$ & $E m x 1^{(\mathrm{Cre} /+} / \mathrm{Pol} / \beta^{f / f t}$ & \\
\hline E14.5 & 51 & 48 & 99 (19) \\
\hline Weaned & 80 & 74 & $154(22)$ \\
\hline
\end{tabular}

Table 3. Genotyping of $\mathrm{Nex}-\mathrm{Cre} / \mathrm{Pol} / \boldsymbol{\beta}^{f / f f l}$ mice

\begin{tabular}{|c|c|c|c|}
\hline \multirow[b]{2}{*}{ Stage } & \multicolumn{2}{|c|}{$\mathrm{Pol} \beta^{f / f l} \times \mathrm{Nex}^{\mathrm{Cre} /+} / \mathrm{Pol} \beta^{f / f l}$} & \multirow{2}{*}{$\begin{array}{l}\text { Total no. } \\
\text { (no. of litters }\end{array}$} \\
\hline & $\overline{P o l} \beta^{f / f t}$ & $\mathrm{Nex} \mathrm{Cre} /+^{\mathrm{C}} / \mathrm{Pol} \beta^{\mathrm{fl} / \mathrm{fl}}$ & \\
\hline E14.5 & 48 & 57 & 105 (17) \\
\hline Weaned & 45 & 55 & $100(16)$ \\
\hline
\end{tabular}

cortex using immunohistochemical analysis with anticleaved caspase-3 antibody. Cleaved caspase-3-positive apoptotic cells were rarely found in E14.5 wild-type mice (Fig. $2 A-C$ ). In accordance with the result in Pol $\beta^{-1-}$ mice, cleaved caspase-3-positive apoptotic cells were remarkably observed in Tuj1-positive postmitotic neurons in the IZ and CP, but not in neural progenitors in the VZ, of Pol $\beta^{\text {del/del }}$ mice at E14.5 (Fig. 2D-F). Emx1-Cre/Pol $\beta^{f l / f l}$ mice displayed a similar distribution of cleaved caspase-3positive cells to Pol $\beta^{\text {del/del }}$ mice (Fig. $2 G-I$ ). In contrast, the apoptotic cells were absent in Nex-Cre/Pol $\beta^{f l / f l}$ mice, which is comparable with wild-type mice (Fig. $2 J-L$ ). To evaluate whether the level of apoptosis correlates with genotype, the laminar distribution of cleaved caspase-3-positive cells was quantified in the developing cortex of each mouse line. The cortical depth was divided into 10 equal bins from the ventricle to the pial surface (Fig. 2M). Cleaved caspase-3-positive cells were abundant in the $\mathrm{CP}$ in both Pol $\beta^{\text {del/del }}$ and Emx1-Cre/Pol $\beta^{\text {fl/fl }}$ mice (bins 7-10, $58 \%$ in Pol ${ }^{\text {del/del }}$ mice and 59\% in Emx1-Cre/Pol $\beta^{\text {flfl }}$ mice), but were less numerous in the VZ (bins 1-5, 19\% in Pol $\beta^{\text {del/del }}$ mice and $13 \%$ in Emx1-Cre/Pol $\beta^{\text {fl/fl }}$ mice) (Fig. $2 M$; Pol ${ }^{\text {delldel }}$ mice vs wild-type: ${ }^{* *} p<0.01, t$ test, Emx1-Cre/Pol $\beta^{f l / f l}$ mice vs wild-type: ${ }^{*} p<0.05,{ }^{* *} p<0.01, t$ test). In contrast, very few apoptotic cells were detected in every layer of either wild-type or Nex-Cre/ Pol ${ }^{f l f l}$ cortex (Fig. 2M). These results indicate that, although apoptosis is predominantly observed in postmitotic neurons in the $\operatorname{Pol} \beta$-deficient cortex, loss of $\operatorname{Pol} \beta$ activity in neural progenitors in the VZ leads to this phenotype.

\section{Pol $\beta$ deficiency increases DSB formation in neural progenitors, thereby inducing $\mathrm{p} 53$-mediated apoptosis}

To investigate the mechanism by which $\operatorname{Pol} \beta$ deficiency in neural progenitors triggers neuronal apoptosis, we considered the possibility that cytotoxic DSBs accumulate in postmitotic neurons (Lee et al., 2001). DSB formation was examined in the conditional mutant cortex by immunohistochemistry with anti- $\gamma \mathrm{H} 2 \mathrm{AX}$ (Ser 139-phoshorylated histone H2AX) antibody. $\gamma \mathrm{H} 2 \mathrm{AX}$ forms foci at DSB sites in the nucleus and is involved in DSB repair (Rogakou et al., 1998, 1999). Even in control Pol ${ }^{f l / f l}$ mice, a few $\gamma \mathrm{H} 2 \mathrm{AX}$ foci formed in a small fraction of Ki67-positive proliferative neural progenitors in the VZ and subventricular zone, but not in Tuj1positive postmitotic neurons in the IZ or the $\mathrm{CP}$ (Fig. $3 A-D, F-I$ ). Notably, an increased number of $\gamma \mathrm{H} 2 \mathrm{AX}$ foci formed in both the $\mathrm{VZ}$ and CP in Emx1-Cre/Polf ${ }^{f l / f l}$ mice (Fig. 3J-M). Conversely, Nex-Cre/Polf ${ }^{f l / f l}$ mice displayed $\gamma \mathrm{H} 2 \mathrm{AX}$ foci formation at a level similar to control Pol $\beta^{f l / f l}$ mice (Fig. $3 N-Q$ ). Immunohistochemical analysis with an antibody to 53BP1, another marker protein of DSB formation (Schultz et al., 2000), confirmed these results (Fig. $3 S-Z, A^{\prime}-D^{\prime}$ ). To quantify the distribution of damaged cells 

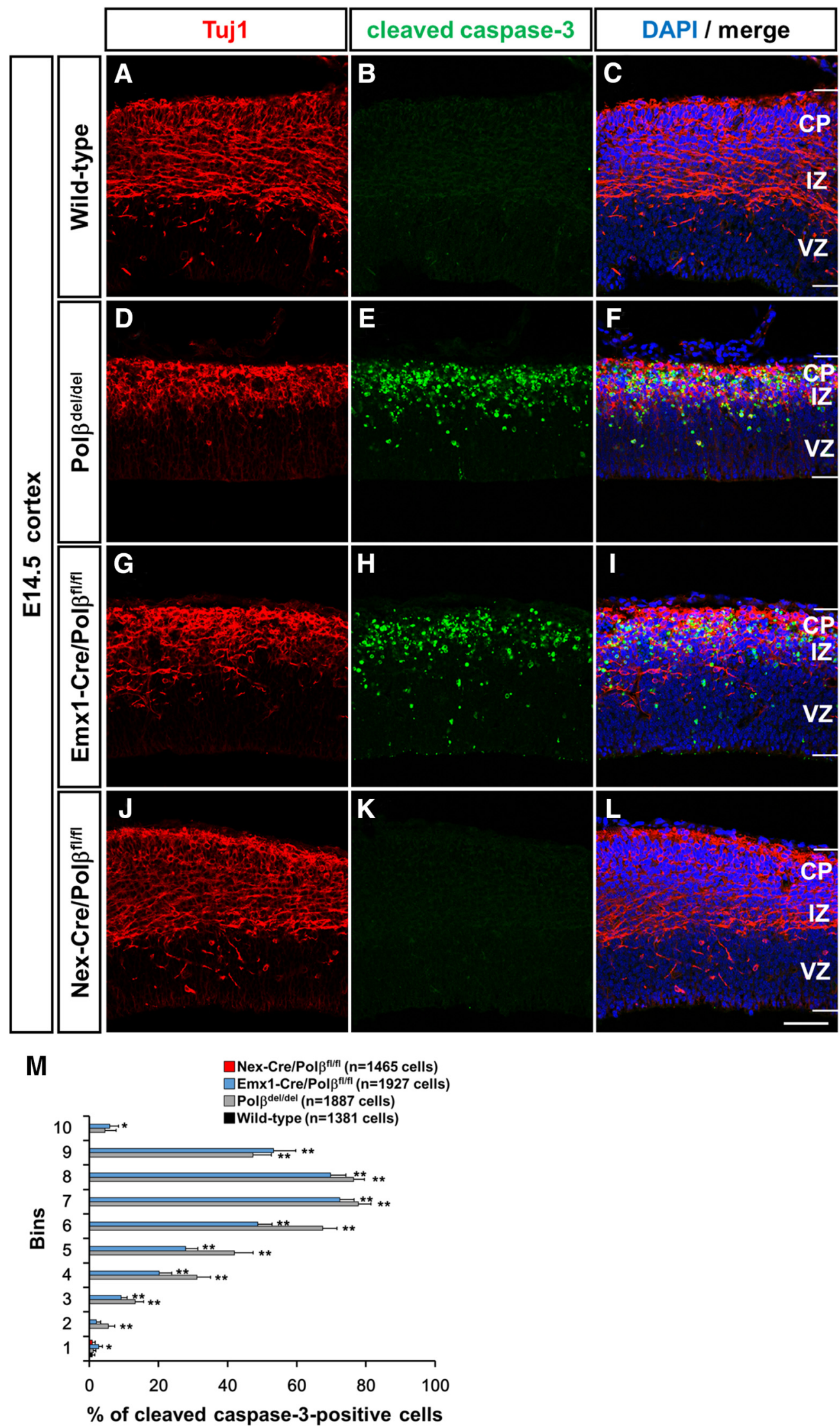

Figure 2. Pol $\beta$ is essential for neural progenitors rather than postmitotic neurons. Immunohistochemistry was performed with anti-Tuj $1(\boldsymbol{A}, \boldsymbol{C}, \boldsymbol{D}, \boldsymbol{F}, \boldsymbol{G}, \boldsymbol{I}, \boldsymbol{J}, \boldsymbol{L})$ and anticleaved caspase-3 $(\boldsymbol{B}, \boldsymbol{C}, \boldsymbol{E}$,

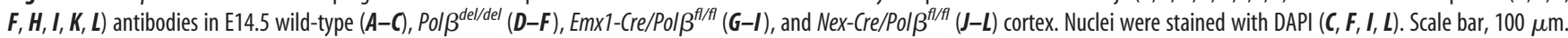
$M$, Distribution histogram of cleaved caspase-3-positive cells in the cortical column of E14.5 wild-type, Pol $\beta^{\text {del/del }}$, Emx $1-C r e / P o l / \beta^{f / f t}$, and Nex-Cre/Pol $\beta^{f / / f l}$ mice. The cortical column was divided into 10 equal bins from the ventricle to the pial surface. VZ, bins $1-4 ; \mathrm{IZ}$, bins $5-7 ;\left(\mathrm{P}\right.$, bins $8-10$ in wild-type and Nex-Cre/Pol $\beta^{\text {f/ff }}$ cortex. VZ, bins $1-5$; (Figure legend continues.) 

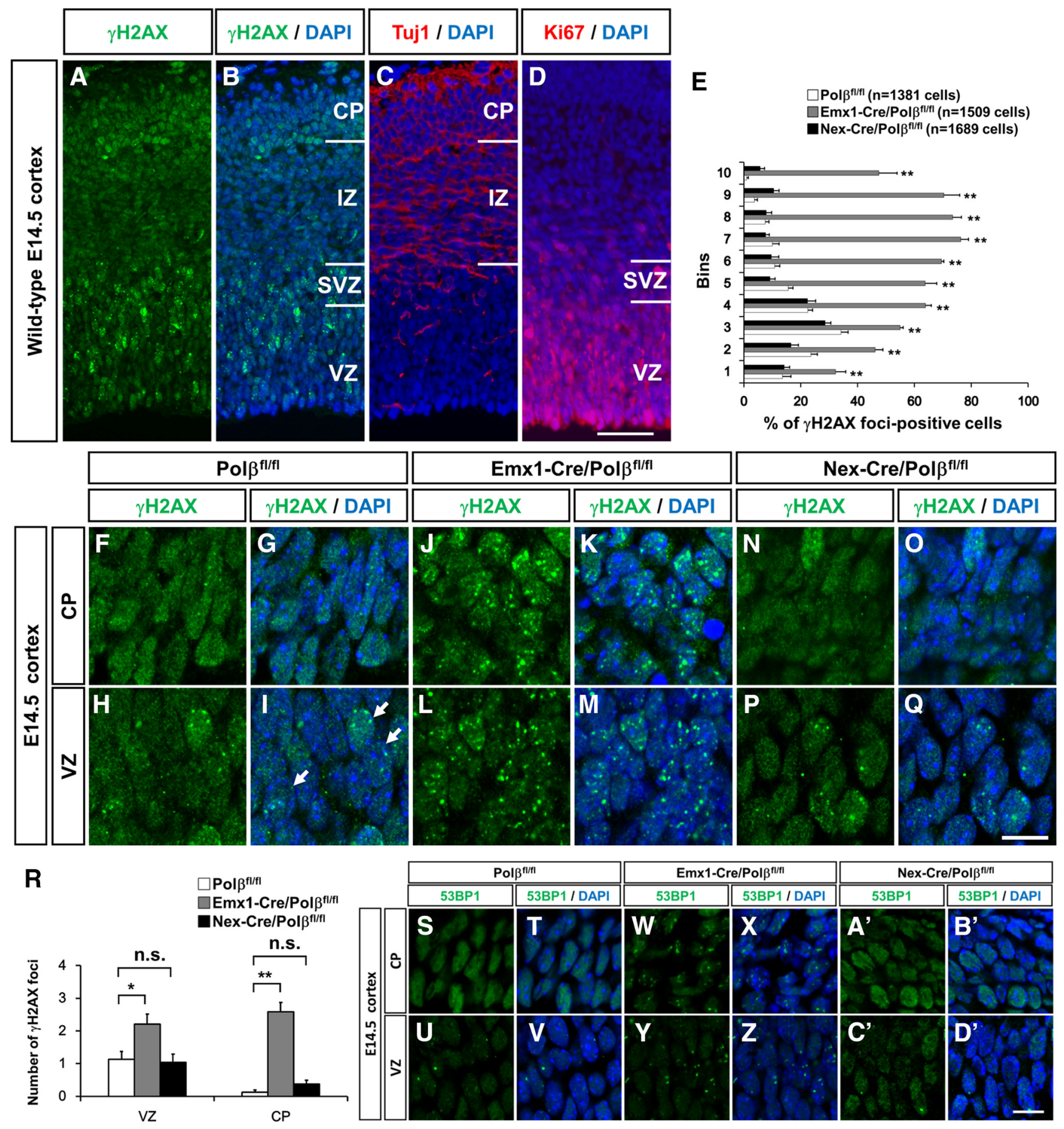

Figure 3. Pol $\beta$ deficiency increases DSBs in neural progenitors, which remain in postmitotic neurons. Immunohistochemistry was performed with anti- $\gamma H 2 A X(A, B, F-Q)$, anti-Tuj $1(\boldsymbol{C})$, and

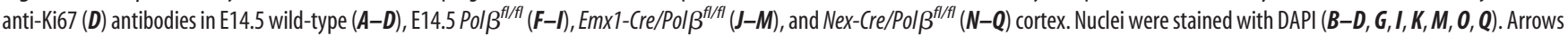
indicate $\gamma \mathrm{H} 2 \mathrm{AX}$ foci. Scale bars: $\boldsymbol{D}, 50 \mu \mathrm{m} ; \mathbf{Q}, 10 \mu \mathrm{m}$. E, Distribution histogram of $\gamma \mathrm{H} 2 \mathrm{AX}$ foci-positive cells in the cortical column in $E 14.5$ Pol $\beta^{f / / f t}$, Emx 1 -Cre/Pol $\beta^{f / f t l}$, and Nex-Cre/Pol $\beta^{f / / f t}$ mice. The cortical column was divided into 10 equal bins from the ventricle to the pial surface. Values in parentheses are the number of cells analyzed. Data are mean \pm SEM from at least three different brains. Significant difference from Pol $\beta^{f / f / f}$ mice: ${ }^{* *} p<0.01$ (Student'st test). $R$, Histogram showing the number of $\gamma \mathrm{H} 2 \mathrm{AX}$ foci in individual VZ and CP cells of E14.5 Pol $\beta^{f / f t}$, Emx $1-\mathrm{Cre} / \mathrm{Po} / \beta^{f / f f l}$, and $\mathrm{Nex}$-Cre/Pol $\beta^{f / f f}$ cortex. Data are the mean \pm SEM from 24 cells in each of three different brains. Significant difference from Pol ${ }^{f / / f t}$ mice: ${ }^{*} p<0.05$ (Student's t test); ${ }^{* *} p<0.01$ (Student's $t$ test).

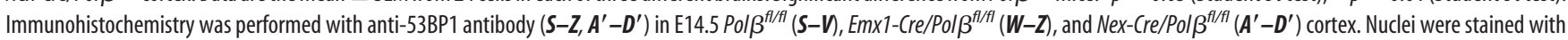
$\operatorname{DAPI}\left(\boldsymbol{T}, \boldsymbol{V}, \boldsymbol{X}, \boldsymbol{Z}, \boldsymbol{B}^{\prime}, \boldsymbol{D}^{\prime}\right)$. Scale bar, $10 \mu \mathrm{m}$.

$$
\leftarrow
$$

(Figure legend continued.) IZ, bin 6; CP, bins 7-10 in Pol $\beta^{\text {del/del }}$ and Emx 1-Cre/Pol $\beta^{f / f l}$ cortex. Values in parentheses are the number of cells analyzed. Data are mean \pm SEM from at least three different brains. Significant difference from wild-type mice: ${ }^{*} p<0.05$ (Student's $t$ test); ${ }^{* *} p<0.01$ (Student's t test). in the developing cortex, $\gamma \mathrm{H} 2 \mathrm{AX}$ foci-possessing cells were counted in each bin as described above (Fig. 3E). $\gamma \mathrm{H} 2 \mathrm{AX}$ focipositive cells in Pol $\beta^{f l f l}$ mice were more numerous in the $\mathrm{VZ}$ and subventricular zone (bins $1-4,24 \%$ ) than in the $\mathrm{CP}$ (bins 8-10, 4\%) (Fig. 3E). In Emxl-Cre/Polf $\beta^{f / f l}$ mice, the $\gamma \mathrm{H} 2 \mathrm{AX}$ foci- 

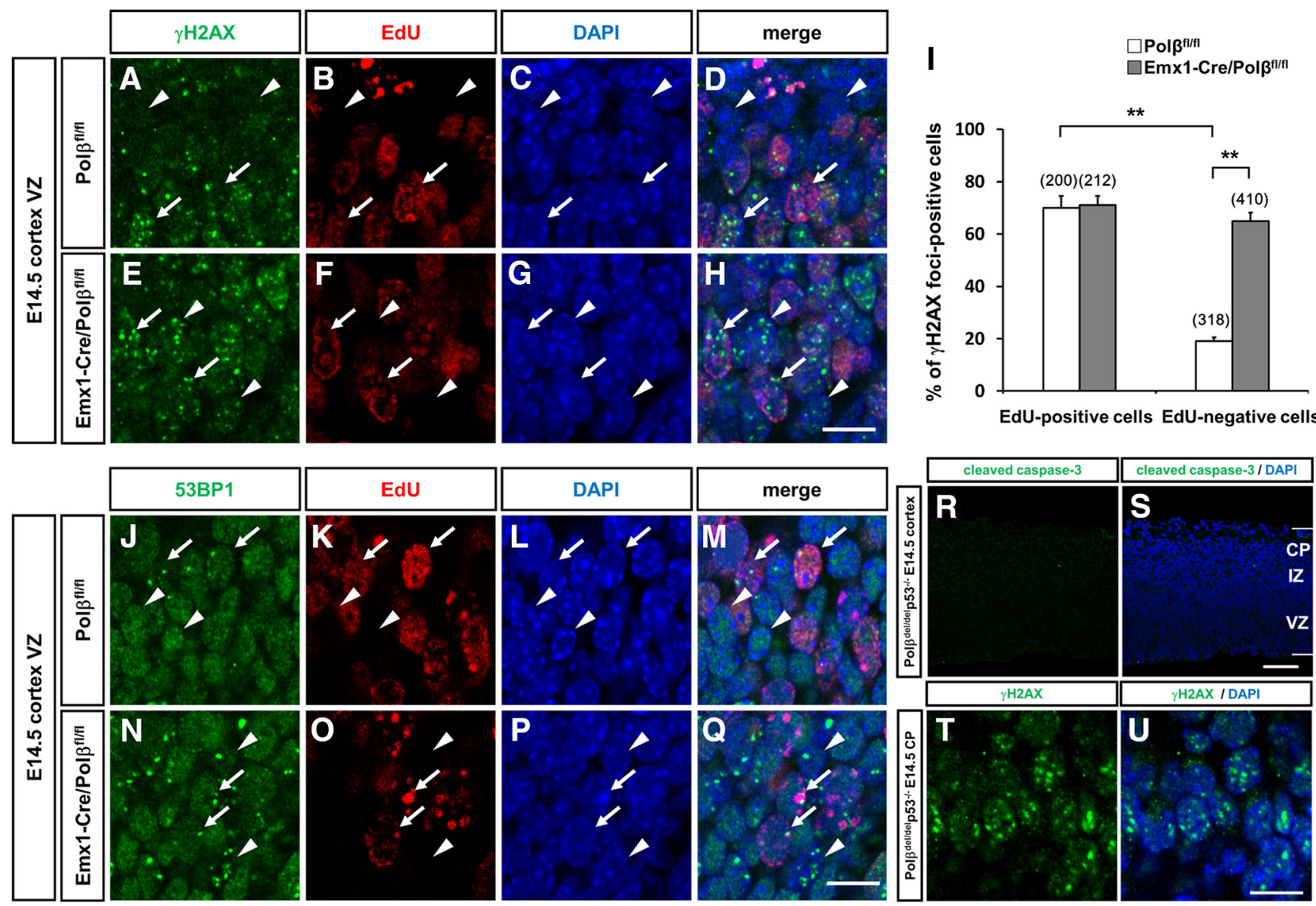

Figure 4. DSBs arise during $S$ phase and lead to $p 53$-mediated neuronal apoptosis in Pol $\beta$-deficient cortex. EdU staining $(\boldsymbol{B}, \boldsymbol{D}, \boldsymbol{F}, \boldsymbol{H})$ and immunohistochemistry for $\gamma \mathrm{H} 2 \mathrm{AX}(\boldsymbol{A}, \boldsymbol{D}, \boldsymbol{E}, \boldsymbol{H})$ were

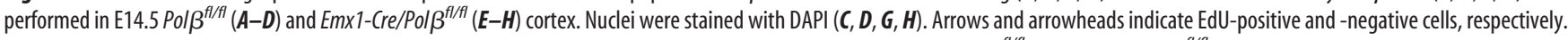
Scale bar, $10 \mu \mathrm{m}$. I, Quantitative analysis of $\gamma \mathrm{H} 2 \mathrm{AX}$ foci-positive cells in either EdU-positive or -negative cells in the VZ of $P$ ol $/ \beta^{f / / f l}$ and $E m x 1$-Cre/Pol $\beta^{f / / f}$ cortex. Values in parentheses are the number of neural progenitors analyzed. Data are mean \pm SEM from three different brains. Significant difference: ${ }^{* *} p<0.01$ (Student's $t$ test). EdU staining $(\boldsymbol{K}, \boldsymbol{M}, \mathbf{O}, \mathbf{Q})$ and immunohistochemistry for

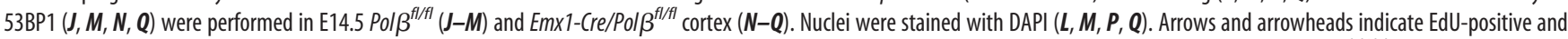
-negative cells, respectively. Scale bar, $10 \mu \mathrm{m}$. Immunohistochemistry was performed with anticleaved caspase-3 $(\boldsymbol{R}, \boldsymbol{S})$ and anti- $\gamma \mathrm{H} 2 \mathrm{AX}$ antibodies $(\boldsymbol{T}, \boldsymbol{U})$ in E14.5 Pol $\beta^{\text {del/del }} p 53^{-/-} \operatorname{cortex}^{\text {N Nuclei }}$ were stained with $\operatorname{DAPI}(\boldsymbol{S}, \boldsymbol{U})$. Scale bars: $\boldsymbol{S}, 100 \mu \mathrm{m} ; \boldsymbol{U}, 10 \mu \mathrm{m}$.

possessing cells were abundant in all layers, particularly in the $\mathrm{CP}$ (VZ: bins 1-5, 53\%, CP: bins 7-10, 69\%, Emx1-Cre/Pol $\beta^{f / f l}$ mice vs wild-type: $p<0.01, t$ test). In contrast, the distribution of DNAdamaged cells in Nex-Cre/Polf ${ }^{f l / f l}$ mice (VZ: bins 1-4, 20\%, CP: bins $8-10,6 \%$ ) was comparable with that in Pol $\beta^{f l f l}$ mice (Fig. $3 E)$. These results indicate that $\operatorname{Pol} \beta$ deficiency in neural progenitors leads to excessive DSB formation.

To characterize the DNA damage level in individual VZ and $\mathrm{CP}$ cells, we counted $\gamma \mathrm{H} 2 \mathrm{AX}$ foci in the nuclei. The number of $\gamma \mathrm{H} 2 \mathrm{AX}$ foci in both VZ and CP cells was significantly larger in Emx1-Cre/Pol $\beta^{f l / f l}$ mice compared with Pol $\beta^{f l / f l}$ mice (Fig. 3R; Pol $^{f l / f l}$ vs Emxl-Cre/Pol $\beta^{f l f l f}$, VZ: $1.13 \pm 0.25,2.21 \pm 0.31, p=$ $0.021, \mathrm{CP}: 0.13 \pm 0.069,2.58 \pm 0.29, p=0.00045, t$ test $)$. In contrast, the number of $\gamma \mathrm{H} 2 \mathrm{AX}$ foci in $\mathrm{Nex}-\mathrm{Cre} / \mathrm{Pol} \mathrm{\beta}^{f l / f l}$ mice was similar to that in Pol $\beta^{f l f l}$ mice (Fig. 3R). Moreover, the number of $\gamma \mathrm{H} 2 \mathrm{AX}$ foci was comparable between VZ and CP cells in Emx1Cre/Pol $\beta^{f l / f l}$ mice, although $\gamma \mathrm{H} 2 \mathrm{AX}$ foci were rare in the CP cells in $\mathrm{Pol} \beta^{f l / f l}$ and Nex-Cre/Pol$\beta^{f l f l}$ mice. These results suggest that the majority of DSBs by $\operatorname{Pol} \beta$ deficiency in neural progenitors remain unrepaired in postmitotic neurons.

We further investigated whether DSB formation is associated with DNA replication in the VZ by observing DSB and replication sites simultaneously in the nucleus. To visualize DNA replication,
EdU was injected into E14.5 pregnant mice, and its incorporation was examined after $30 \mathrm{~min}$. This short-term labeling should allow us to identify active replication in the nucleus (O'Keefe et al., 1992). The majority of the EdU-positive cells in the VZ contained $\gamma \mathrm{H} 2 \mathrm{AX}$ foci in both Pols ${ }^{f l / f l}(70 \pm 4.4 \%)$ and Emxl-Cre/Pol $\beta^{f l f l}$ $(71 \pm 3.5 \%)$ cortex (Fig. $4 A-I$ ), although the number of $\gamma \mathrm{H} 2 \mathrm{AX}$ foci in individual cells was much larger in Emx1-Cre/Pol $\beta^{l / f l}$ mice (see above). In contrast, EdU-negative VZ cells more frequently showed $\gamma \mathrm{H} 2 \mathrm{AX}$ foci in Emxl-Cre/Polf ${ }^{f l / f l}$ mice $(65 \pm 3.2 \%)$ than in Pol $\beta^{f l / f l}$ mice $(19 \pm 1.5 \%)$ (Fig. 4I; EdU-negative cells in Pol $\beta^{f l / f l}$ mice vs EdU-negative cells in Emx1-Cre/Pol $\beta^{t / f l}$ mice: $p=0.0002$, $t$ test, EdU-positive vs EdU-negative cells in Pol $\beta^{f / f l}$ mice: $p=0.00015, t$ test). Similar foci formation of 53BP1 was also observed in the VZ (Fig. 4J-Q). Thus, although DSBs likely formed at DNA replication sites during $S$ phase in both wild-type and $\operatorname{Pol} \beta$-deficient neural progenitors, it seems that most of these DSBs remain unrepaired until the next cell cycle in the $\operatorname{Pol} \beta$-deficient neural progenitors or postmitotic neurons.

Because it is known that a genome guardian p53 mediates apoptosis induced by DSBs in cortical neurons (Frank et al., 2000; Gao et al., 2000), we examined $\gamma \mathrm{H} 2 \mathrm{AX}$ foci formation in $P o l \beta^{\text {del/del }} p 53^{-/-}$ mice. As the loss of $\mathrm{p} 53$ completely suppresses neuronal apoptosis in Pol $\beta^{-/-}$mice (Sugo et al., 2004), apoptosis could be inhibited 


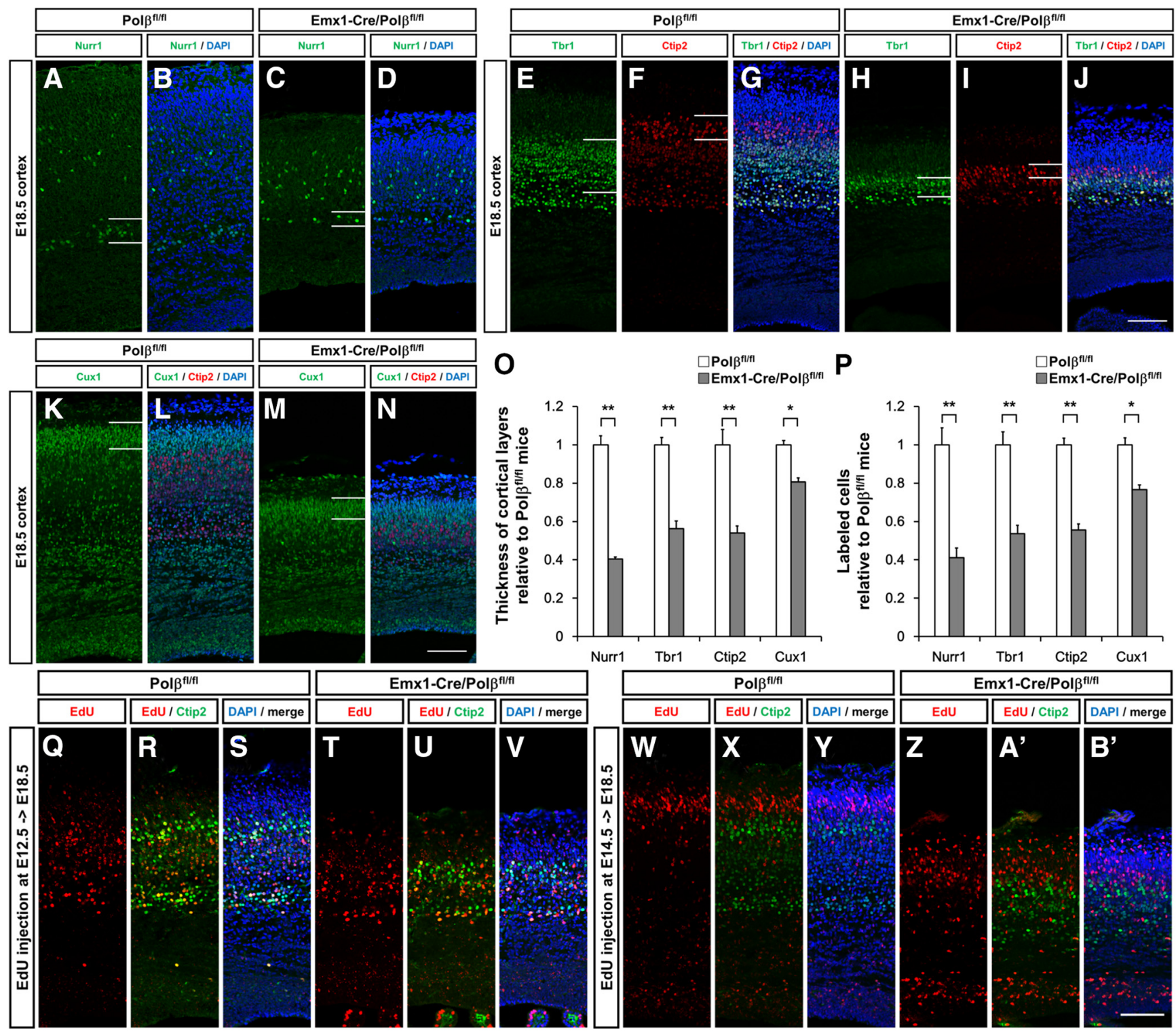

Figure 5. Pol $\beta$ deficiency preferentially reduces the survival of deep-layer neurons in the developing cortex. Immunohistochemistry was performed with anti-Nurr $1(\boldsymbol{A}-\boldsymbol{D})$, anti-Tbr1 $(\boldsymbol{E}, \boldsymbol{G}, \boldsymbol{H}, \boldsymbol{J})$,

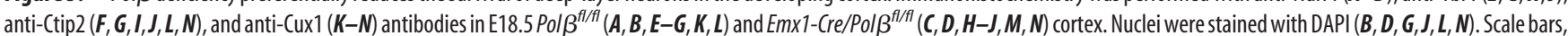
$100 \mu \mathrm{m}$. O, The thickness of each marker-positive layer in $E m \times 1-\left(\mathrm{Cr} / \mathrm{Pol} / \beta^{f / f / f}\right.$ mice relative to $P o / \beta^{f / f f l}$ mice. Data are mean \pm SEM from at least three different brains. Significant difference from Pol $\beta^{f / f t}$ mice: ${ }^{*} p<0.05$ (Student's $t$ test); ${ }^{* *} p<0.01$ (Student's $t$ test). $P$, The number of layer marker-positive cells in each cortical layer of $E m \times 1-C r e / P o l / \beta^{f / f l}$ mice relative to $P o l \beta^{f / / f l}$ mice. The columns analyzed were $270 \mu \mathrm{m}$ wide. Data are mean \pm SEM from at least three different brains. Significant difference from $P o / \beta^{f / f t}$ mice: ${ }^{*} p<0.05$ (Student'st test); ${ }^{* *} p<0.01$ (Student'st test).

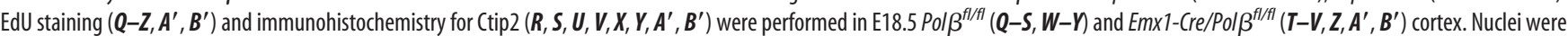
stained with DAPI $\left(S, V, Y, B^{\prime}\right)$. Scale bar, $100 \mu \mathrm{m}$.

in $P o l \beta^{\text {del/del }} p 53^{-1-}$ mice if DNA damage is due to a lack of Pol $\beta$ induced apoptosis. We found that, indeed, apoptosis was completely attenuated in the CP of Pol $\beta^{\text {del/del }} p 53^{-/-}$cortex, despite extensive DSB formation (Fig. $4 R-U$ ). Together, these results indicate that $\operatorname{Pol} \beta$ deficiency leads to increased DSB formation in neural progenitors and the subsequent activation of the p53-mediated apoptotic pathway in postmitotic neurons.

\section{Pol $\beta$ deficiency differently affects cell viability in each} cortical layer

Although cortical neurons show extensive apoptosis in Emx1Cre/Pol $\beta^{f l f l}$ mice, a substantial number of neurons are still viable in the CP (Fig. 2). To investigate the impact of $\mathrm{Pol} \beta$ deficiency on cortical cytoarchitecture, immunohistochemistry was performed with antibodies for layer-specific molecules in $P o l \beta^{f l / f l}$ and Emx1-Cre/Pol $\beta^{f l f l}$ mice at E18.5. Nurr1 (Fig. 5A-D), Tbr1 (Fig. $5 E, G, H, J$ ), Ctip2 (Fig. $5 F, G, I, J$ ), and Cux1 (Fig. $5 K-N$ ) antibodies were used for subplate, layer VI, layer V, and layer II-IV markers, respectively (Hevner et al., 2001; Arimatsu et al., 2003; Nieto et al., 2004; Arlotta et al., 2005). Although the laminar structure formed normally in Emxl-Cre/Pol/ ${ }^{f l f l}$ mice, the thickness and the number of cells in each layer was significantly lower in Emx1-Cre/Pol $\beta^{f l f l}$ (Fig. 5C,D,H-J,M,N) than in Pol ${ }^{f l / f l}$ cortex (Fig. $5 A, B, E-G, K, L$ ). The extent of reduction was more prominent in the Nurr1-, Tbr1-, and Ctip2-positive deep layers than in the Cux1-positive upper layers (Fig. 5O; Nurr1: $0.4 \pm$ 0.011, $p=0.0094$, Tbr1: $0.56 \pm 0.04, p=0.001$, Ctip2: $0.54 \pm$ $0.038, p=0.008$, Cuxl: $0.81 \pm 0.021, p=0.023, t$ test; Fig. $5 P$; Nurr1: $0.41 \pm 0.052, p=0.00014$, Tbr1: $0.54 \pm 0.043, p=$ 0.0008, Ctip2: $0.56 \pm 0.032, p=0.0061$, Cux1: $0.77 \pm 0.023$, 


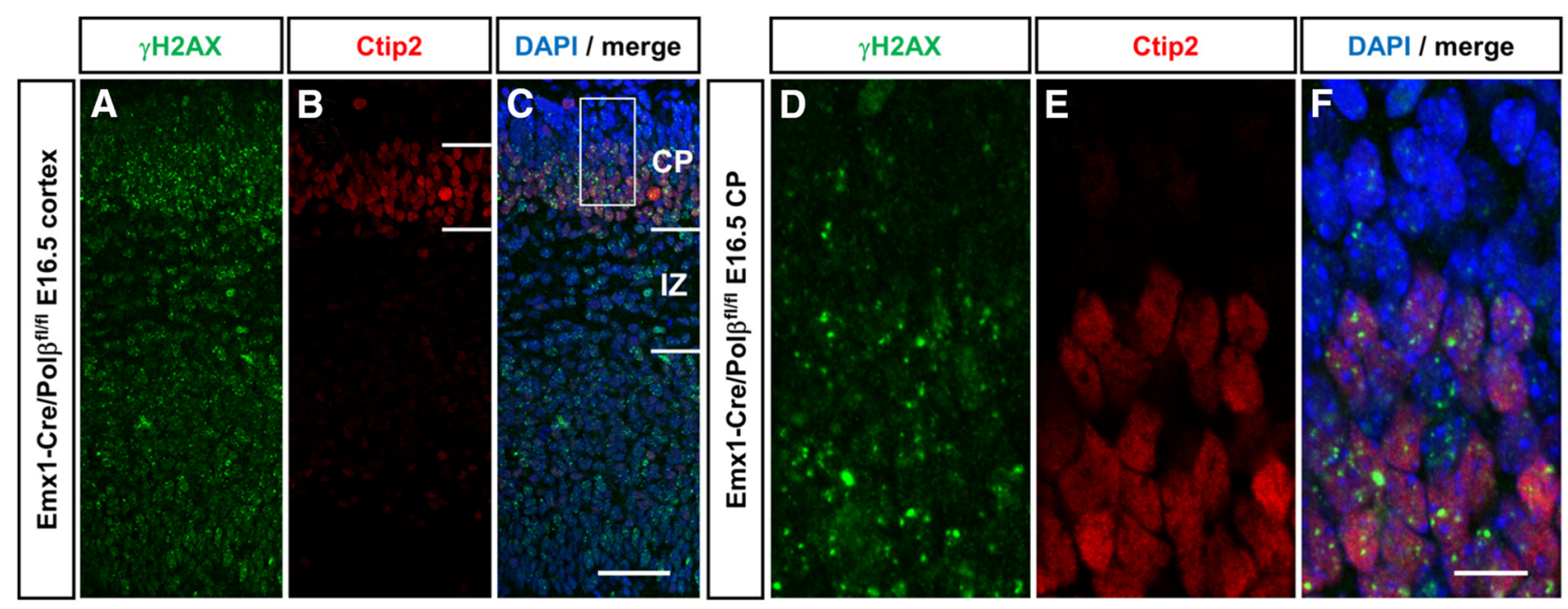

G

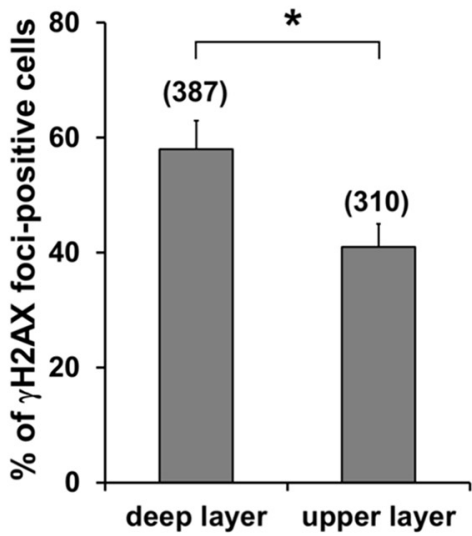

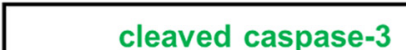

cleaved caspase-3
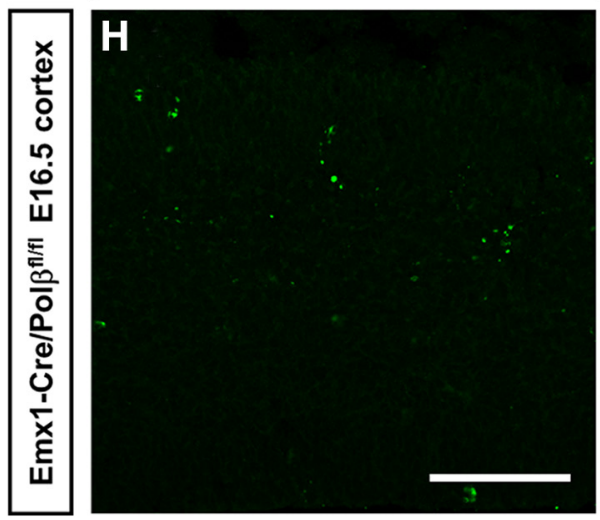

cleaved caspase-3 / DAPI



Figure 6. DSBs are relatively accumulated in deep-layer neurons compared with upper-layer neurons in Pol $\beta$-deficient cortex. Immunohistochemistry was performed with anti- $\gamma \mathrm{H} 2 \mathrm{AX}$ $(\boldsymbol{A}, \boldsymbol{C}, \boldsymbol{D}, \boldsymbol{F})$ and $\mathrm{Ctip2}(\boldsymbol{B}, \boldsymbol{C}, \boldsymbol{E}, \boldsymbol{F})$ antibodies in E16.5 Emx1-Cre/Pol $\boldsymbol{\beta}^{\mathrm{f} / \mathrm{fl}}$ cortex. Nuclei were stained with DAPI (C, $\left.\boldsymbol{F}\right)$. Scale bar, $100 \mu \mathrm{m}$. D-F, Magnified images of the boxed area in $\boldsymbol{C}$. Scale bar, 10 $\mu \mathrm{m} . G$, Quantitative analysis of $\gamma \mathrm{H} 2 \mathrm{AX}$ foci-positive cells in the Ctip2-positive deep and -negative upper layers of E16.5 Emx1-Cre/Pol $\beta^{f / / f l}$ cortex. Values in parentheses are the number of neurons analyzed. Error bars indicate the mean \pm SEM from three different brains. Significant difference between the layers: ${ }^{*} p<0.05$ (Student's $t$ test). Immunohistochemistry was performed with anticleaved caspase-3 antibody $(\boldsymbol{H}, \boldsymbol{I})$ in E16.5 Emx1-Cre/Po/ $\beta^{f / f l}$ cortex. Nuclei were stained with DAPI $(\boldsymbol{I})$. Scale bar, $100 \mu \mathrm{m}$.

$p=0.031, t$ test). Furthermore, to examine the possibility that $\operatorname{Pol} \beta$ may affect cell cycle and neuronal laminar fate, we performed birth date labeling with EdU. In accordance with previous reports (Angevine and Sidman, 1961; Takahashi et al., 1995), early-born neurons labeled with EdU at E12.5 were mainly located in Ctip2-positive deep layers (Fig. 5Q-V), and late-born neurons labeled at E14.5 were present in the upper layers at E18.5 in both $P o l \beta^{f l f l}$ and Emx1-Cre/Pol $\beta^{f l f l}$ mice (Fig. $5 W-Z, A^{\prime}, B^{\prime}$ ). Together, these results suggested that deep-layer neurons undergo more extensive apoptosis compared with upper-layer neurons, which resulted in deep layers that were thinner than upper layers in $\mathrm{Pol} \beta$-deficient cortex.

To further examine whether the extensive apoptosis in the deep-layer neurons is related to the extent of DSBs, the number of $\gamma \mathrm{H} 2 \mathrm{AX}$ foci-positive cells was counted in Emx1-Cre/Pol $\beta^{f l / f l}$ mice at E16.5 (Fig. 6A-G), when only a minor amount of cleaved caspase-3-positive apoptosis was observed in the CP (Fig. 6 H,I). We found that $\gamma \mathrm{H} 2 \mathrm{AX}$ foci-positive cells were densely distributed in the Ctip2-positive deep layers (Fig. 6A-F). The ratio of $\gamma \mathrm{H} 2 \mathrm{AX}$ foci-positive cells was significantly higher in Ctip2positive deep-layer neurons $(58 \pm 4.9 \%)$ than in Ctip2-negative upper-layer neurons $(41 \pm 4.5 \%)$ (Fig. $6 G ; p=0.0284, t$ test), suggesting the possibility that extensive apoptosis in the $\mathrm{CP}$ accompanies increased DSBs.
Pol $\beta$ deficiency affects axonal growth in a subset of deep-layer neurons

In Emxl-Cre/Pol $\beta^{f l f l}$ mice, DSBs were frequently observed, even in surviving neurons in the CP (Fig. 3). Such DSB may also affect cortical cell differentiation. We asked whether the DSBs affect axon formation in damaged deep-layer neurons (approximately layer V) in Emx1-Cre/Pol $\beta^{f l f l}$ mice. To observe axons originating from the deep-layer cells, EGFP plasmid was transfected into VZ cells by in utero electroporation at E13.5, when these cells are mostly destined to become deep-layer neurons. Then, axonal projection was examined at E16.5, when initial axonal projections have been formed. In Pol $\beta^{f l f l}$ mice, the majority of EGFPlabeled neurons were localized in deep layer and extended their axons toward the corpus callosum or internal capsule (Fig. 7A-C) (Custo Greig et al., 2013). Similarly, callosal and subcortical projections were observed in Emx1-Cre/Pol ${ }^{f l / f l}$ mice, but the length of corticofugal axons was significantly shorter than in $P o l \beta^{\text {fl/fl }}$ mice (Fig. 7D-G; Pol $\beta^{f l f l}$ vs Emx1-Cre/Pol $\beta^{f l f l}: 704 \pm 41 \mu \mathrm{m}$, $520 \pm 27 \mu \mathrm{m}, p=0.008, U$ test). In contrast, the commissural axonal growth was indistinguishable between $P o l \beta^{f l f l}$ and $E m \times 1$ Cre/Pol $\beta^{f l f l}$ mice (Fig. 7D-G). Consistent with this analysis, immunohistochemistry with anti-TAG1 antibody also demonstrated corticofugal axonal growth defects in Emx1-Cre/Pol $\beta^{f l f l}$ mice (Fig. 7H-O) (Denaxa et al., 2001). TAG1-positive axons 




G


Figure 7. Pol $\beta$ deficiency affects corticofugal axonal growth. Cortical layer IV neurons were labeled with EGFP by in utero electroporation at E13.5 and analyzed at E16.5. Immunohistochemical analyses were performed with anti-GFP antibody $(\boldsymbol{A}, \boldsymbol{C}, \boldsymbol{D}, \boldsymbol{F})$ in Pol $\beta^{f / f f}(\boldsymbol{A}-\boldsymbol{C})$ and $E m \times 1-C r e / P o l / \beta^{f / f t}$ mice $(\boldsymbol{D}-\boldsymbol{F})$. Nuclei were stained with DAPI $(\boldsymbol{B}, \boldsymbol{C}, \boldsymbol{E}, \boldsymbol{F})$. Scale bar, $500 \mu \mathrm{m}$. Frames indicate electroporated area. Asterisks indicate the center of electroporated area. Arrow and arrowhead indicate tips of corticofugal axons and commissural axons, respectively. $\mathbf{G}$, Quantitative analysis of the


SEM from 11 sections of 4 Pol $\beta^{f / f f l}$ brains or 16 sections of 5 Emx $1-C r e / P o / \beta^{f / f f l}$ brains. Immunohistochemistry was performed with anti-TAG-1 antibody $(\boldsymbol{H}-\mathbf{0})$ in E16.5 Pol $\beta^{f / / f l}(\boldsymbol{H}-\boldsymbol{K})$ and Emx1-Cre/Pol $\beta^{f / f l}(\boldsymbol{L}-\mathbf{0})$ forebrain. Nuclei were stained with DAPI $(\boldsymbol{I}, \boldsymbol{K}, \boldsymbol{M}, \mathbf{0})$. Scale bar, $500 \mu \mathrm{m} . \boldsymbol{J}, \boldsymbol{K}, \boldsymbol{N}, \boldsymbol{O}$, Magnified images of the boxed area in $\boldsymbol{I}$ and $\boldsymbol{M}$, respectively. Scale bar, $300 \mu \mathrm{m}$. IC, Internal capsule. Arrows indicate TAG-1-positive axons. P, Relative gene expression of Gap43, Apc, Tubb6, and Rplp1 was examined by qRT-PCR in E14.5 Pol $\beta^{f / f f}$ and Emx 1 -Cre/Pol $\beta^{f / f f}$ cortices. Gap43 and Apc are known to relate to axonal growth. Tubb6 and Rplp1 are ubiquitously expressed genes. Significant difference from Pol $\beta^{f / f f} \operatorname{cortices:~}^{* *} p<0.01$ (Student's $t$ test).

were clearly observed in the internal capsule of E16.5 Pol/ $\beta^{f l f l}$ mice, but few were observable in Emx1-Cre/Pol $\beta^{f l f l}$ mice (Fig. $7 \mathrm{~L}, \mathrm{~N})$. In accordance with this result, qRT-PCR analysis of the embryonic cortex demonstrated that expression of axon growthrelated genes, such as Gap43 and Apc, was downregulated in Emx1-Cre/Pol $\beta^{f l / f l}$ compared with Pol ${ }^{\text {fl/fl }}$ mice (Fig. 7P; Gap43: $0.47 \pm 0.058, p=0.0015$, Apc: $0.35 \pm 0.075, p=0.00074, t$ test $)$ (Kruger et al., 1998; Shi et al., 2004). These results demonstrate that axonal extension of subcortically projecting deep-layer neurons is severely affected in $\operatorname{Pol} \beta$ deficient cortex, suggesting that the genome instability leads to neural defects even in the subset of cortical cells that escape from cell death.

Pol $\beta$ deficiency increases DSBs arising from base damage and DNA demethylation intermediates

Finally, we investigated the mechanistic basis for DSB induction in neural progenitors. $\operatorname{Pol} \beta$ deficiency is generally thought to increase nicks and gaps as single-strand breaks (SSBs) (Wilson et al., 2000). However, we found that DSBs arose during replication in neural progenitors (see above). SSBs may be converted to DSBs due to replication fork collapse in S phase (Kuzminov, 2001). To test this possibility, cultured cortical progenitor cells were treated with the alkylating agent MMS for $1 \mathrm{~h}$. MMS treatment produces base damage that yields substrates for BER (Beranek, 1990). After the treatment, we observed DSB formation using immunocytochemistry with anti- $\gamma \mathrm{H} 2 \mathrm{AX}$ antibody (Fig. $8 A-P$ ). Similar to in vivo analysis, the control culture revealed that the number of $\gamma \mathrm{H} 2 \mathrm{AX}$ foci was greater in EdU-positive Emx1-Cre/Pol $\beta^{\text {fl/fl }}$ cells (Fig. $8 I-L, Q$; mean number of $\gamma \mathrm{H} 2 \mathrm{AX}$ foci: $2.3 \pm 0.39$ ) than in Pol $^{f l / f l}$ cells (Fig. $8 A-D, Q ; 0.8 \pm 0.24$ ). Importantly, the MMS treatment significantly increased the number of $\gamma \mathrm{H} 2 \mathrm{AX}$ foci in Emx1-Cre/Pol及 fl/fl cells (Fig. $8 M-Q ; 6.0 \pm 0.79$ ) relative to Pol $f^{f l f l}$ cells (Fig. $8 E-H, Q ; 3.4 \pm 0.89$, control Pol $\beta^{f l f l}$ cells vs control Emx1-Cre/Pol $\beta^{\text {fl/fl }}$ cells: $p=0.0024, t$ test, MMS treated Pol ${ }^{f l / f l}$ cells vs MMS treated Emx1-Cre/Pol ${ }^{f l / f l}$ cells: $p=0.023, t$ test, control vs MMS treated Pol $\beta^{f / f l}$ cells: $p=0.0025, t$ test, 

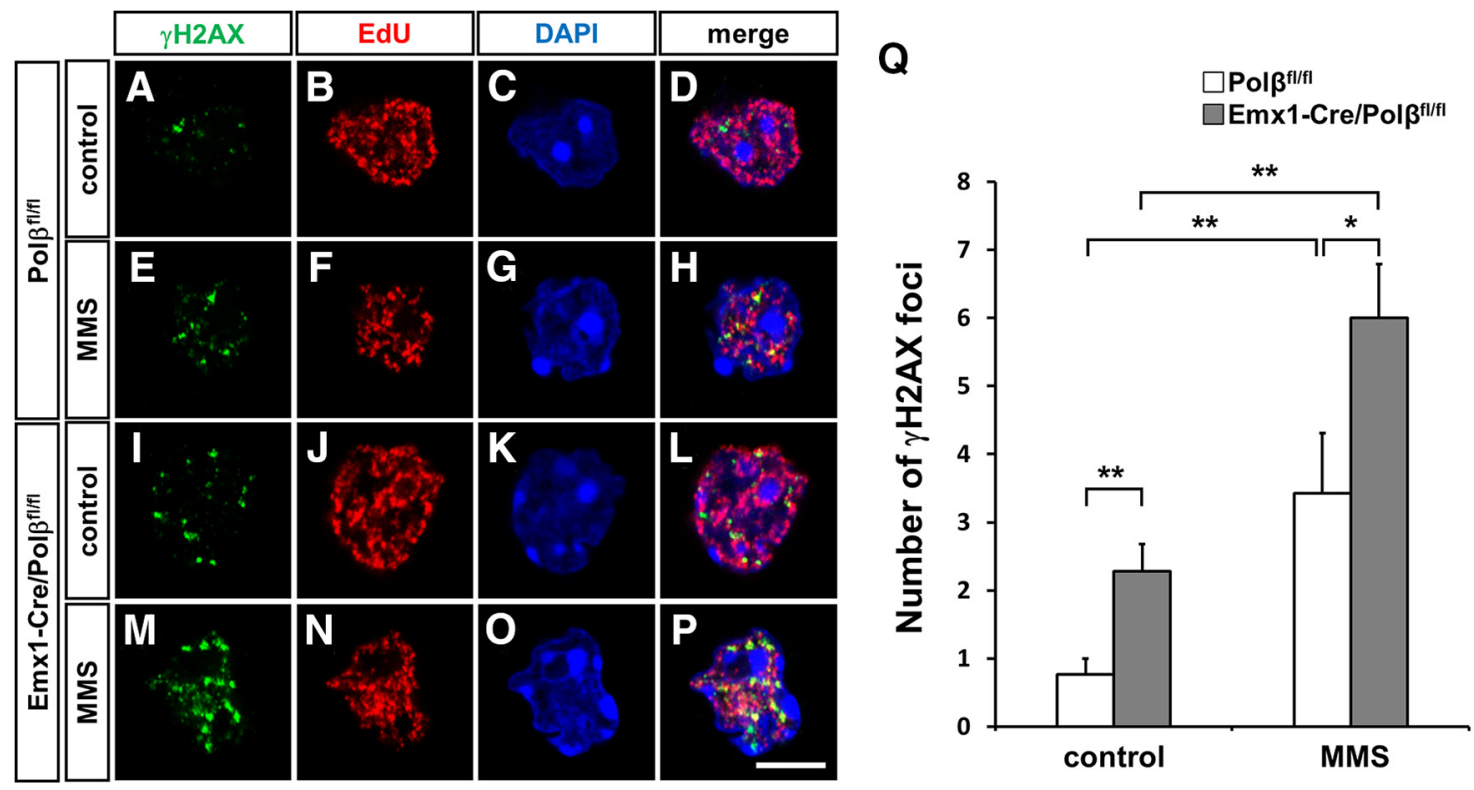

Figure 8. Pol $\beta$ deficiency in neural progenitors increases $D S B s$ following MMS treatment. EdU staining $(\boldsymbol{B}, \boldsymbol{D}, \boldsymbol{F}, \boldsymbol{H}, \boldsymbol{J}, \boldsymbol{L}, \boldsymbol{N}, \boldsymbol{P})$ and immunocytochemistry for $\gamma \mathrm{H} 2 \mathrm{AX}(\boldsymbol{A}, \boldsymbol{D}, \boldsymbol{E}, \boldsymbol{H}, \boldsymbol{I}, \boldsymbol{L}, \boldsymbol{M}, \boldsymbol{P})$ were performed in cultured neural progenitors from E14.5 Pol $\beta^{f / f f f}(\boldsymbol{A}-\boldsymbol{H})$ and $E m x 1$-Cre/Pol $\beta^{f / f f l}(I-P)$ cortex. Nuclei were stained with DAPI $(\boldsymbol{C}, \boldsymbol{D}, \mathbf{G}, \boldsymbol{H}, \boldsymbol{K}, \boldsymbol{L}, \mathbf{O}, \boldsymbol{P})$. The cells were untreated $(\boldsymbol{A}-\boldsymbol{D}, \boldsymbol{I}-\boldsymbol{L})$ or treated with $1 \mathrm{~mm}$ MMS $(\boldsymbol{E}-\boldsymbol{H}, \boldsymbol{M}-\boldsymbol{P})$. Scale bar, $5 \mu \mathrm{m}$. Q, Histogram shows the number of $\gamma \mathrm{H} 2 \mathrm{AX}$ foci in individual EdU-positive cells. Values indicate the mean \pm SEM from 24 Pol $\beta^{\text {fl/ffl }}$ or Emx1-Cre/Pol $\beta^{f / f l}$ cells. Significant difference: ${ }^{*} p<0.05$ (Student's $t$ test); ${ }^{* *} p<0.01$ (Student's $t$ test).

control vs MMS treated Emx1-Cre/Polf ${ }^{f l f l}$ cells: $p=0.00029$, $t$ test). This result indicates that base damage is frequently converted to DSBs during replication in $\mathrm{Pol} \beta$-deficient neural progenitors.

In mammalian active DNA demethylation, TET1 converts $5 \mathrm{mC}$ to specific base modifications, such as $5 \mathrm{hmC}$, leading to its replacement by BER (Bhutani et al., 2011). Because it is suggested that $\operatorname{Pol} \beta$ is involved in this process (Weber et al., 2016), we investigated whether the epigenetic base modification is removed by BER in Pol $\beta$-deficient cultured cortical progenitor cells. For this, cultured cortical cells were treated with vitamin $\mathrm{C}$ for $24 \mathrm{~h}$, following the previous observation that vitamin $\mathrm{C}$ increases the level of 5hmC by activating TET1 (Blaschke et al., 2013). As expected, immunoblot analysis with anti-5hmC antibody showed increased levels of $5 \mathrm{hmC}$ in genomic DNA after vitamin $\mathrm{C}$ treatment (Fig. 9B), whereas the levels of $5 \mathrm{mC}$ in genomic DNA were approximately similar between E14.5 Pol $\beta^{f l f l}$ and Emx1-Cre/ Pol $\beta^{f l f l}$ cortex (Fig. 9A). In Pol$\beta^{f l f l}$ cells, the number of $\gamma \mathrm{H} 2 \mathrm{AX}$ foci in Nestin-positive cells was unchanged with or without the treatment (Fig. 9C-J, S). On the other hand, vitamin C treatment significantly increased the number of $\gamma \mathrm{H} 2 \mathrm{AX}$ foci relative to the control in Nestin-positive Emx1-Cre/Pol $\beta^{\text {flfl }}$ cells (Fig. 9K-S; control vs vitamin C-treated Emx1-Cre/Pol $\beta^{f l f l}$ cells: $0.58 \pm 0.2$, $1.25 \pm 0.24, p=0.036, t$ test; vitamin C-treated Pol $\beta^{f l f l}$ vs Emx1Cre/Pol $\beta^{f l f l}$ cells: $0.33 \pm 0.12,1.25 \pm 0.24, p=0.001, t$ test). This result suggests that $\mathrm{Pol} \beta$-dependent BER is necessary for the DNA demethylation process in neural progenitors, thereby contributing to the competence of neural progenitors.

\section{Discussion}

In the present study, we demonstrated that the loss of $\mathrm{Pol} \beta$ led to DSB formation in neural progenitors, and subsequently to p53mediated apoptosis in postmitotic neurons, resulting in abnormal cortical layer formation. The DSBs also caused axon growth defects in a subset of surviving neurons. In addition, treatment of either MMS or vitamin C markedly enhanced DSB formation in cultured $\operatorname{Pol} \beta$-deficient neural progenitors. These results suggest that pathological base damage and epigenetic base modification in neural progenitors cause neuronal developmental defects. Thus, genome stability by $\mathrm{Pol} \beta$-dependent BER is required for the competence of neural progenitors, thereby contributing to cortical development.

\section{Pol $\beta$-dependent BER is required for neural progenitors} rather than postmitotic neurons in the developing cortex $\operatorname{Pol} \beta$ is thought to be required for genome stability in postmitotic neurons because the alternative proliferating cell nuclear antigendependent long patch BER pathway does not function in neurons (Wei and Englander, 2008; Akbari et al., 2009; Sykora et al., 2013). Indeed, the previous and present results demonstrate that massive neuronal apoptosis occurs in $\operatorname{Pol} \beta$-deficient mice (Sugo et al., 2000). However, the present findings provide a new insight that genome stability by $\operatorname{Pol} \beta$-dependent BER is more important in neural progenitors than in postmitotic neurons in the developing cortex.

The present study revealed that $\gamma \mathrm{H} 2 \mathrm{AX}$ foci-positive DSBs are localized at DNA replication sites and accumulate in $\mathrm{Pol} \beta$ deficient neural progenitors, even though $\operatorname{Pol} \beta$ is expressed ubiquitously and independently in the cell cycle (Figs. 3, 4) (Zmudzka et al., 1988). Although $\operatorname{Pol} \beta$ is not involved in the DSB repair pathway, SSBs (BER intermediates) may give rise to DSBs during DNA replication in $\operatorname{Pol} \beta$-deficient neural progenitors. This would not be surprising, as SSBs are known to be converted to DSBs by replication fork collapse (Kuzminov, 2001). Consistent with our findings in cultured neural progenitors (Fig. 8), $\mathrm{Pol} \beta$-deficient MEF cells show increased $\gamma \mathrm{H} 2 \mathrm{AX}$ foci at $\mathrm{S}$ phase and chromatid breaks at $\mathrm{M}$ phase in response to MMS treatment (Sobol et al., 2003; Pascucci et al., 2005; Senejani et al., 2012; Ensminger et al., 2014). Moreover, similar to $\mathrm{Pol} \beta$-deficient mice, neural progenitors deficient in other BER-related components (such as Xrcc1 and Pnkp), which are thought to accumulate SSBs, also show increased DSBs in the developing cortex (Lee et al., 2009; Shimada et al., 2015).

We also found a small number of DSBs in wild-type neural progenitors, but not in postmitotic neurons (Fig. 3). The DSBs 
A



B
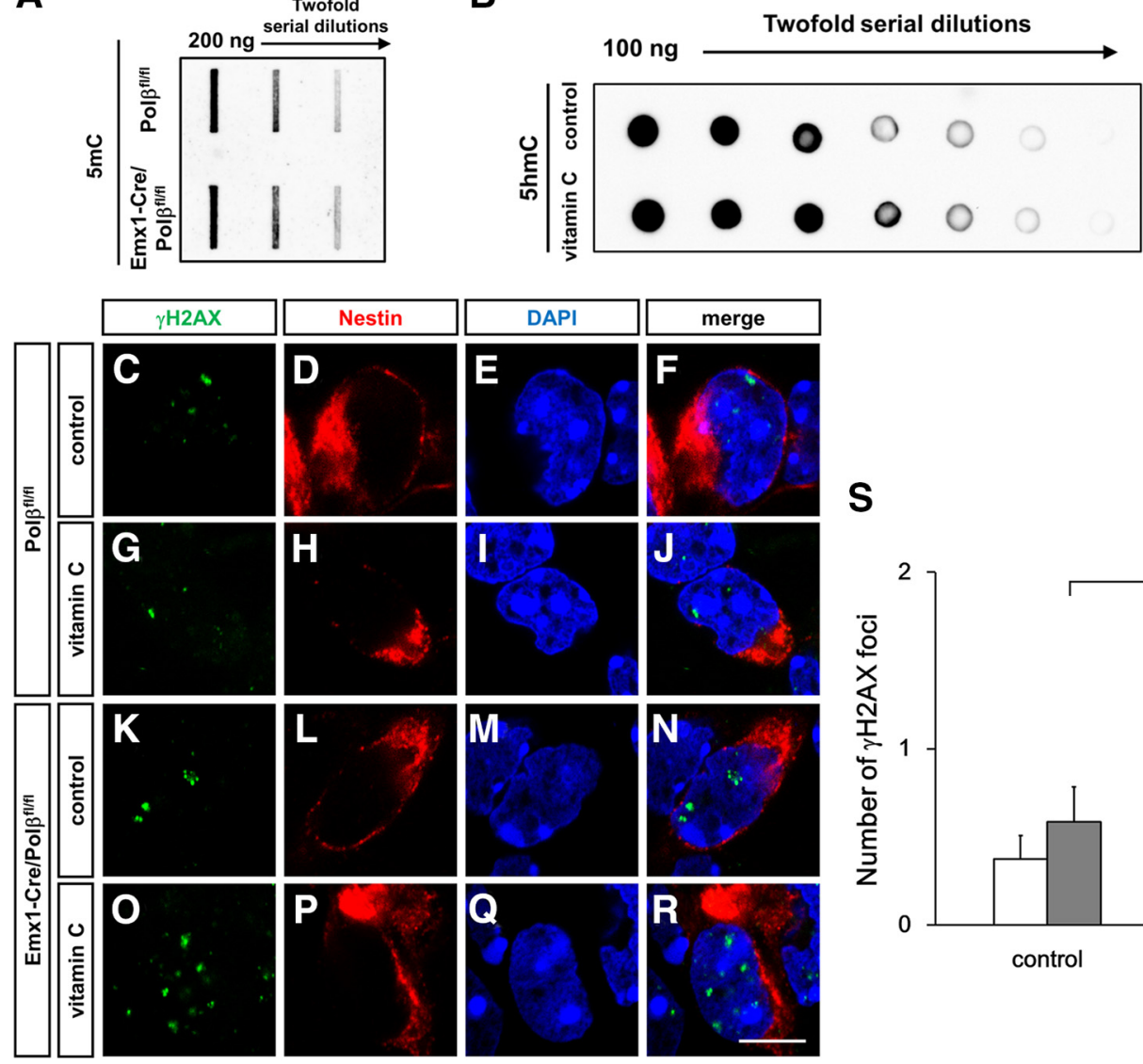

S
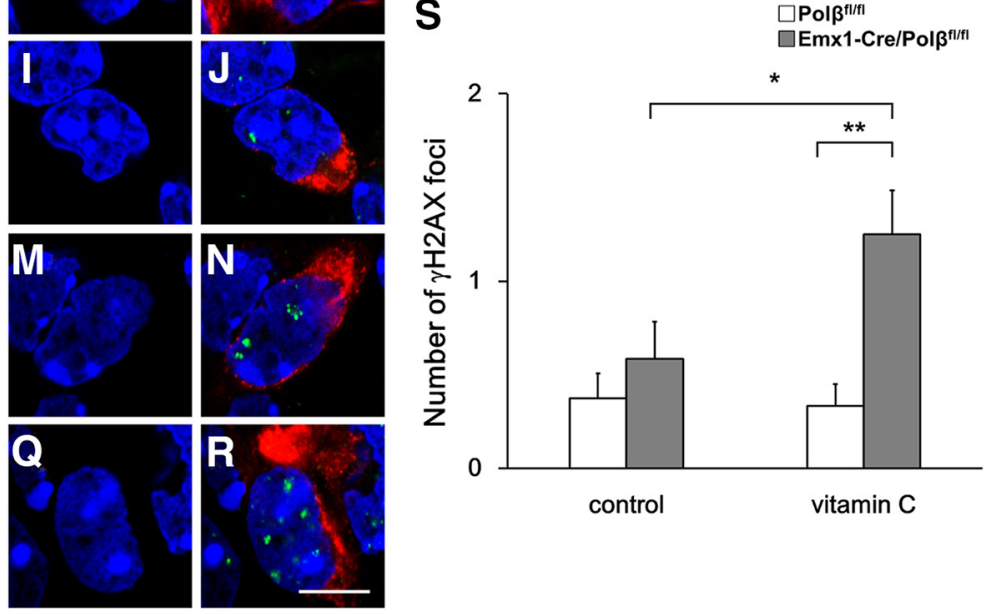

Figure 9. Accumulation of the DNA demethylation intermediate $5 \mathrm{hmC}$ increases DSBs in Pol $\beta$-deficient neural progenitors. $A$, Immunoblot analysis shows $5 \mathrm{mC}$ global levels in genomic DNA from E14.5 Pol $\beta^{f / f f l}$ and Emx1-Cre/Po/ $\beta^{f / f f}$ mouse cortex. $\boldsymbol{B}$, Immunoblot analysis shows global $5 \mathrm{hmC}$ levels in genomic DNA. Dissociated cell cultures from E14.5 cortices were incubated with or without vitamin ( for $24 \mathrm{~h}$. Immunocytochemistry was performed with anti- $\gamma \mathrm{H} 2 \mathrm{AX}(\boldsymbol{C}, \boldsymbol{F}, \mathbf{G}, \boldsymbol{J}, \boldsymbol{K}, \mathbf{N}, \mathbf{O}, \boldsymbol{R})$ and anti-Nestin $(\boldsymbol{D}, \boldsymbol{F}, \boldsymbol{H}, \boldsymbol{J}, \boldsymbol{L}, \boldsymbol{N}, \boldsymbol{P}, \boldsymbol{R})$ antibodies in dissociated cells from E14.5 Pol $\boldsymbol{\beta}^{f / / f f}(\mathbf{C}-\boldsymbol{J})$ and Emx1-Cre/Pol $\beta^{f / f l}$ mouse cortex $(\boldsymbol{K}-\boldsymbol{R})$. Nuclei were stained with DAPI $(\boldsymbol{E}, \boldsymbol{F}, \boldsymbol{I}, \boldsymbol{J}, \boldsymbol{M}, \boldsymbol{N}, \mathbf{Q}, \boldsymbol{R})$. The cells were untreated $(\boldsymbol{C}-\boldsymbol{F}, \boldsymbol{K}-\boldsymbol{N})$ or treated with $100 \mu \mathrm{g} / \mathrm{ml} \mathbf{V i t a m i n} C(\boldsymbol{G}-\mathbf{J}, \mathbf{0}-\boldsymbol{R})$. Scale bar, $5 \mu \mathrm{m}$. $S$, Histogram showing the number of $\gamma \mathrm{H} 2 \mathrm{AX}$ foci in individual Nestin-positive cells. Values indicate the mean \pm SEM from 24 Pol $\beta^{f / f l}$ or Emx 1 -Cre/Pol $\beta^{f / f l}$ cells. Asterisks indicate a significant difference $\left({ }^{*} p<0.05,{ }^{* *} p<0.01\right.$, Student's t test).

were, furthermore, predominantly observed in $S$ phase in wildtype, similar to $\operatorname{Pol} \beta$-deficient neural progenitors (Fig. 4). Therefore, SSBs, perhaps due to insufficient BER, may promote genome instability even in wild-type neural progenitors.

\section{Neuronal apoptosis in Pol $\beta$-deficient developing cortex}

Previous studies have shown that apoptosis occurs in the developing cortex, although the extent observed varied between different detection methods and developmental stages (Ferrer et al., 1992; Blaschke et al., 1996; Yang et al., 2004; Depaepe et al., 2005). These findings raised the hypothesis that an overproduction of neurons and the subsequent elimination processes are required for normal cortical development (Kuan et al., 2000). Contrary to these observations, it is unlikely that $\operatorname{Pol} \beta$-dependent BER is involved in developmental apoptosis. Indeed, the present study showed that this pathway is crucial to maintain cellular homeostasis by repairing pathological and physiological DNA damage in neural progenitors (Figs. 8, 9).

The formation of DSBs as a result of $\operatorname{Pol} \beta$ deficiency occurs in neural progenitors, and the consequent apoptosis was mainly observed in the CP (Figs. 2, 3). These results indicate that, although neural progenitors accumulate many DSBs due to $\operatorname{Pol} \beta$ deficiency, they do not undergo apoptosis. It is known that DSBs activate ataxia telangiectasia-mutated signaling, which induces neuronal apoptosis via phosphorylation of p53 in the CP (Lee et al., 2001). Indeed, a previous report and our current results showed that p53 deficiency completely rescued apoptotic phenotype in $\operatorname{Pol} \beta$-deficient mice (Fig. 4) (Sugo et al., 2004). The difference in apoptosis may be related to the accumulated level of phosphorylated p53 in apoptotic cells and nonapoptotic cells. Supporting this notion, the reduction of p53 phosphorylation level attenuates neuronal apoptosis in Pol $\beta^{-/-} p 53^{+/-}$mice (Sugo et al., 2004; Sugo et al., 2007). Thus, these data suggest that the accumulation level of phosphorylated p53 is insufficient to induce damage-related apoptosis in neural progenitors.

Similarly to Pol $\beta$-deficient mice, mice deficient in nonhomologous end-joining (NHEJ) also show aberrant apoptosis in postmitotic neurons and subsequent microcephaly that are identical to the corresponding human mutants (Barnes et al., 1998; Gao et al., 1998; O'Driscoll et al., 2001; Gatz et al., 2011). The phenotypic similarity between $\operatorname{Pol} \beta$ and NHEJ-deficient mice may be attributed to DSB-induced apoptosis in the IZ and CP, rather than less proliferation and neurogenesis in the VZ.

\section{Pol $\beta$ deficiency affects cortical layer formation and axonal growth}

The present results demonstrate that DSBs lead to apoptosis in postmitotic cells in the $\mathrm{CP}$ and result in thinner cortical layers. On the other hand, the laminar profile of $\operatorname{Pol} \beta$-deficient cortex 
seems to be normal (Fig. 5), suggesting that abundant DSBs may not influence laminar fate and cell cycle progression in $\mathrm{Pol} \beta$ deficient neural progenitors (Fig. 3). However, DSB formation was different between layers: DSBs were found more abundantly in deep-layer neurons than upper-layer neurons in $\operatorname{Pol} \beta$-deficient mice (Fig. 6). One possibility is that early neural progenitors may not have enough time to repair DSBs by NHEJ in $\mathrm{G}_{1}$ phase, because the cell cycle length of $G_{1}$ phase is shorter in early neural progenitors than that in late progenitors (Caviness et al., 1995).

Axonal growth was also affected in $\operatorname{Pol} \beta$-deficient cortex (Fig. 7). It is likely that DSB-containing neurons can survive but may have some deficiencies in axon growth property. Indeed, the expression of the axon growth-related genes Gap43 and Apc was downregulated (Fig. 7), suggesting a transcriptional change induced by DSBs affects axonal growth in $\operatorname{Pol} \beta$-deficient cortex. Furthermore, subcortical, but not callosal, projection neurons in deep layers displayed severe axonal growth defects in $\operatorname{Pol} \beta$ deficient cortex (Fig. 7), indicating that DSBs caused by $\operatorname{Pol} \beta$ deficiency affect axonal growth in a subset of neurons. In accordance with this view, a previous study demonstrated that only specific tracts, such as thalamocortical projections and anterior commissure, show abnormalities in Pol $\beta^{-1-} p 53^{-1-}$ mice (Sugo et al., 2004). Therefore, a cell-type-specific aspect may produce different extents of DSB formation in Pol $\beta$-deficient cortex, resulting in cell-type-specific phenotypes in developing neurons.

\section{Pol $\beta$-dependent BER is necessary for DNA demethylation process in neural progenitors}

DNA methylation level in the neuronal gene promoter and/or enhancer regions influences neuronal development (Fan et al., 2001; Tyssowski et al., 2014). Analyses of DNA methylation patterns reveal that active DNA demethylation via BER changes its patterns during neuronal development (Cortázar et al., 2011; Cortellino et al., 2011; Wheldon et al., 2014). In this study, we showed that DNA demethylation intermediates induced DSB formation in $\operatorname{Pol} \beta$-deficient neural progenitors (Fig. 9). Our finding provides the genetic evidence that $\operatorname{Pol} \beta$ is an essential enzyme in these DNA demethylation processes. Although the endogenous source of DSBs in the developing cortex remains a controversial issue (Karanjawala et al., 2002), the physiological DNA demethylation process in neural progenitors may be susceptible to genome instability during cortical development. Moreover, if the DSBs are fixed by error-prone NHEJ, which is the only DSB repair pathway in neurons, insertions/deletions are frequently introduced in neuronal gene promoter and/or enhancer regions (Lu et al., 2004; Lieber, 2010). These DSBs and/or DSB-induced de novo mutations may perturb transcription of neuronal genes (Sharma et al., 2016). Together, our findings suggest that neuronal differentiation is dependent on DNA demethylation via $\mathrm{Pol} \beta$ dependent BER in neural progenitors.

\section{The impact of Pol $\beta$ deficiency on cortical development and function}

Together, these data suggest the following paradigm. DNA base damage is formed in neural progenitors by not only pathological damage but also epigenetic modification of the genome. In normal development, the DNA base damage can be repaired by the Pol $\beta$-dependent BER pathway. In particular, the BER completes DNA demethylation, promoting gene expression. But, in the absence of $\operatorname{Pol} \beta$, DNA gaps may be retained and converted into cytotoxic DSBs by replication, so that DSBs accumulate in postmitotic neurons. Based on the extent of DSBs, various phenotypes will appear in cortical development. Some neurons with a large extent of DSBs undergo apoptosis, whereas other neurons with the lesser extent can survive but exhibit abnormal differentiation. Thus, our findings provide a new insight that regulation of genome stability by $\operatorname{Pol} \beta$-dependent BER in neural progenitors is crucial for neuronal differentiation in cortical development.

Several developmental defects observed in $\operatorname{Pol} \beta$-deficient cortex are suspected to lead to brain dysfunction. Individuals with NHEJ gene mutations demonstrate intellectual disability related to microcephaly (Rosin et al., 2015). It is likely that accumulation of DSBs and/or DSB-induced de novo mutations in $\operatorname{Pol} \beta$ deficient cortex leads to cortical developmental disorders. Pol $\beta$ polymorphisms have not been identified in the CNS, although several mutations in BER-related genes are identified to be associated with human brain dysfunction (Date et al., 2001; Takashima et al., 2002; Shen et al., 2010; Sobol, 2012; Hoch et al., 2017).

\section{References}

Akbari M, Pena-Diaz J, Andersen S, Liabakk NB, Otterlei M, Krokan HE (2009) Extracts of proliferating and non-proliferating human cells display different base excision pathways and repair fidelity. DNA Repair (Amst) 8:834-843. CrossRef Medline

Angevine JB Jr, Sidman RL (1961) Autoradiographic study of cell migration during histogenesis of cerebral cortex in the mouse. Nature 192:766-768. CrossRef Medline

Arimatsu Y, Ishida M, Kaneko T, Ichinose S, Omori A (2003) Organization and development of corticocortical associative neurons expressing the orphan nuclear receptor Nurr1. J Comp Neurol 466:180-196. CrossRef Medline

Arlotta P, Molyneaux BJ, Chen J, Inoue J, Kominami R, Macklis JD (2005) Neuronal subtype-specific genes that control corticospinal motor neuron development in vivo. Neuron 45:207-221. CrossRef Medline

Barnes DE, Stamp G, Rosewell I, Denzel A, Lindahl T (1998) Targeted disruption of the gene encoding DNA ligase IV leads to lethality in embryonic mice. Curr Biol 8:1395-1398. CrossRef Medline

Beranek DT (1990) Distribution of methyl and ethyl adducts following alkylation with monofunctional alkylating agents. Mutat Res 231:11-30. CrossRef Medline

Bhutani N, Burns DM, Blau HM (2011) DNA demethylation dynamics. Cell 146:866-872. CrossRef Medline

Blaschke AJ, Staley K, Chun J (1996) Widespread programmed cell death in proliferative and postmitotic regions of the fetal cerebral cortex. Development 122:1165-1174. Medline

Blaschke K, Ebata KT, Karimi MM, Zepeda-Martínez JA, Goyal P, Mahapatra S, Tam A, Laird DJ, Hirst M, Rao A, Lorincz MC, Ramalho-Santos M (2013) Vitamin C induces Tet-dependent DNA demethylation and a blastocyst-like state in ES cells. Nature 500:222-226. CrossRef Medline

Bundo M, Toyoshima M, Okada Y, Akamatsu W, Ueda J, Nemoto-Miyauchi T, Sunaga F, Toritsuka M, Ikawa D, Kakita A, Kato M, Kasai K, Kishimoto T, Nawa H, Okano H, Yoshikawa T, Kato T, Iwamoto K (2014) Increased 11 retrotransposition in the neuronal genome in schizophrenia. Neuron 81:306-313. CrossRef Medline

Caldecott KW (2008) Single-strand break repair and genetic disease. Nat Rev Genet 9:619-631. CrossRef Medline

Caviness VS Jr, Takahashi T, Nowakowski RS (1995) Numbers, time and neocortical neuronogenesis: a general developmental and evolutionary model. Trends Neurosci 18:379-383. CrossRef Medline

Cortázar D, Kunz C, Selfridge J, Lettieri T, Saito Y, MacDougall E, Wirz A, Schuermann D, Jacobs AL, Siegrist F, Steinacher R, Jiricny J, Bird A, Schär P (2011) Embryonic lethal phenotype reveals a function of TDG in maintaining epigenetic stability. Nature 470:419-423. CrossRef Medline

Cortellino S, Xu J, Sannai M, Moore R, Caretti E, Cigliano A, Le Coz M, Devarajan K, Wessels A, Soprano D, Abramowitz LK, Bartolomei MS, Rambow F, Bassi MR, Bruno T, Fanciulli M, Renner C, Klein-Szanto AJ, Matsumoto Y, Kobi D, et al. (2011) Thymine DNA glycosylase is essential for active DNA demethylation by linked deamination-base excision repair. Cell 146:67-79. CrossRef Medline

Custo Greig LC, Woodworth MB, Galazo MJ, Padmanabhan H, Macklis JD (2013) Molecular logic of neocortical projection neuron specification, development and diversity. Nat Rev Neurosci 14:755-769. CrossRef Medline 
Date H, Onodera O, Tanaka H, Iwabuchi K, Uekawa K, Igarashi S, Koike R, Hiroi T, Yuasa T, Awaya Y, Sakai T, Takahashi T, Nagatomo H, Sekijima Y, Kawachi I, Takiyama Y, Nishizawa M, Fukuhara N, Saito K, Sugano S, et al. (2001) Early-onset ataxia with ocular motor apraxia and hypoalbuminemia is caused by mutations in a new HIT superfamily gene. Nat Genet 29:184-188. CrossRef Medline

Deans B, Griffin CS, Maconochie M, Thacker J (2000) Xrcc2 is required for genetic stability, embryonic neurogenesis and viability in mice. EMBO J 19:6675-6685. CrossRef Medline

Denaxa M, Chan CH, Schachner M, Parnavelas JG, Karagogeos D (2001) The adhesion molecule TAG-1 mediates the migration of cortical interneurons from the ganglionic eminence along the corticofugal fiber system. Development 128:4635-4644. Medline

Depaepe V, Suarez-Gonzalez N, Dufour A, Passante L, Gorski JA, Jones KR, Ledent C, Vanderhaeghen P (2005) Ephrin signalling controls brain size by regulating apoptosis of neural progenitors. Nature 435:1244-1250. CrossRef Medline

Ensminger M, Iloff L, Ebel C, Nikolova T, Kaina B, Löbrich M (2014) DNA breaks and chromosomal aberrations arise when replication meets base excision repair. J Cell Biol 206:29-43. CrossRef Medline

Fan G, Beard C, Chen RZ, Csankovszki G, Sun Y, Siniaia M, Biniszkiewicz D, Bates B, Lee PP, Kuhn R, Trumpp A, Poon C, Wilson CB, Jaenisch R (2001) DNA hypomethylation perturbs the function and survival of CNS neurons in postnatal animals. J Neurosci 21:788-797. Medline

Ferrer I, Soriano E, del Rio JA, Alcántara S, Auladell C (1992) Cell death and removal in the cerebral cortex during development. Prog Neurobiol 39: 1-43. CrossRef Medline

Frank KM, Sharpless NE, Gao Y, Sekiguchi JM, Ferguson DO, Zhu C, Manis JP, Horner J, DePinho RA, Alt FW (2000) DNA ligase IV deficiency in mice leads to defective neurogenesis and embryonic lethality via the p53 pathway. Mol Cell 5:993-1002. CrossRef Medline

Fukuchi-Shimogori T, Grove EA (2001) Neocortex patterning by the secreted signaling molecule FGF8. Science 294:1071-1074. CrossRef Medline

Gao Y, Sun Y, Frank KM, Dikkes P, Fujiwara Y, Seidl KJ, Sekiguchi JM, Rathbun GA, Swat W, Wang J, Bronson RT, Malynn BA, Bryans M, Zhu C, Chaudhuri J, Davidson L, Ferrini R, Stamato T, Orkin SH, Greenberg ME, et al. (1998) A critical role for DNA end-joining proteins in both lymphogenesis and neurogenesis. Cell 95:891-902. CrossRef Medline

Gao Y, Ferguson DO, Xie W, Manis JP, Sekiguchi J, Frank KM, Chaudhuri J, Horner J, DePinho RA, Alt FW (2000) Interplay of p53 and DNA-repair protein XRCC4 in tumorigenesis, genomic stability and development. Nature 404:897-900. CrossRef Medline

Gatz SA, Ju L, Gruber R, Hoffmann E, Carr AM, Wang ZQ, Liu C, Jeggo PA (2011) Requirement for DNA ligase IV during embryonic neuronal development. J Neurosci 31:10088-10100. CrossRef Medline

Goebbels S, Bormuth I, Bode U, Hermanson O, Schwab MH, Nave KA (2006) Genetic targeting of principal neurons in neocortex and hippocampus of NEX-Cre mice. Genesis 44:611-621. CrossRef Medline

Gu H, Marth JD, Orban PC, Mossmann H, Rajewsky K (1994) Deletion of a DNA polymerase $\beta$ gene segment in T cells using cell type-specific gene targeting. Science 265:103-106. CrossRef Medline

Gu Y, Sekiguchi J, Gao Y, Dikkes P, Frank K, Ferguson D, Hasty P, Chun J, Alt FW (2000) Defective embryonic neurogenesis in Ku-deficient but not DNA-dependent protein kinase catalytic subunit-deficient mice. Proc Natl Acad Sci U S A 97:2668-2673. CrossRef Medline

Hevner RF, Shi L, Justice N, Hsueh Y, Sheng M, Smiga S, Bulfone A, Goffinet AM, Campagnoni AT, Rubenstein JL (2001) Tbr1 regulates differentiation of the preplate and layer 6. Neuron 29:353-366. CrossRef Medline

Hoch NC, Hanzlikova H, Rulten SL, Tétreault M, Komulainen E, Ju L, Hornyak P, Zeng Z, Gittens W, Rey SA, Staras K, Mancini GM, McKinnon PJ, Wang ZQ, Wagner JD, Yoon G, Caldecott KW (2017) XRCC1 mutation is associated with PARP1 hyperactivation and cerebellar ataxia. Nature 541:87-91. CrossRef Medline

Iwasato T, Datwani A, Wolf AM, Nishiyama H, Taguchi Y, Tonegawa S, Knöpfel T, Erzurumlu RS, Itohara S (2000) Cortex-restricted disruption of NMDAR1 impairs neuronal patterns in the barrel cortex. Nature 406: 726-731. CrossRef Medline

Karanjawala ZE, Murphy N, Hinton DR, Hsieh CL, Lieber MR (2002) Oxygen metabolism causes chromosome breaks and is associated with the neuronal apoptosis observed in DNA double-strand break repair mutants. Curr Biol 12:397-402. CrossRef Medline

Kruger K, Tam AS, Lu C, Sretavan DW (1998) Retinal ganglion cell axon progression from the optic chiasm to initiate optic tract development requires cell autonomous function of GAP-43. J Neurosci 18:5692-5705. Medline

Kuan CY, Roth KA, Flavell RA, Rakic P (2000) Mechanisms of programmed cell death in the developing brain. Trends Neurosci 23:291-297. CrossRef Medline

Kuzminov A (2001) Single-strand interruptions in replicating chromosomes cause double-strand breaks. Proc Natl Acad Sci U S A 98:82418246. CrossRef Medline

Lee Y, Chong MJ, McKinnon PJ (2001) Ataxia telangiectasia mutateddependent apoptosis after genotoxic stress in the developing nervous system is determined by cellular differentiation status. J Neurosci 21 : 6687-6693. Medline

Lee Y, Katyal S, Li Y, El-Khamisy SF, Russell HR, Caldecott KW, McKinnon PJ (2009) The genesis of cerebellar interneurons and the prevention of neural DNA damage require XRCC1. Nat Neurosci 12:973-980. CrossRef Medline

Lieber MR (2010) The mechanism of double-strand DNA break repair by the nonhomologous DNA end-joining pathway. Annu Rev Biochem 79: 181-211. CrossRef Medline

Lindahl T (1993) Instability and decay of the primary structure of DNA. Nature 362:709-715. CrossRef Medline

Lindahl T, Wood RD (1999) Quality control by DNA repair. Science 286: 1897-1905. CrossRef Medline

Lu T, Pan Y, Kao SY, Li C, Kohane I, Chan J, Yankner BA (2004) Gene regulation and DNA damage in the ageing human brain. Nature 429:883891. CrossRef Medline

McConnell MJ, Lindberg MR, Brennand KJ, Piper JC, Voet T, Cowing-Zitron C, Shumilina S, Lasken RS, Vermeesch JR, Hall IM, Gage FH (2013) Mosaic copy number variation in human neurons. Science 342:632-637. CrossRef Medline

McKinnon PJ (2013) Maintaining genome stability in the nervous system. Nat Neurosci 16:1523-1529. CrossRef Medline

Nieto M, Monuki ES, Tang H, Imitola J, Haubst N, Khoury SJ, Cunningham J, Gotz M, Walsh CA (2004) Expression of Cux-1 and Cux-2 in the subventricular zone and upper layers II-IV of the cerebral cortex. J Comp Neurol 479:168-180. CrossRef Medline

Niimi N, Sugo N, Aratani Y, Koyama H (2005) Genetic interaction between DNA polymerase beta and DNA-PKcs in embryogenesis and neurogenesis. Cell Death Differ 12:184-191. CrossRef Medline

Noguchi Y, Hirabayashi T, Katori S, Kawamura Y, Sanbo M, Hirabayashi M, Kiyonari H, Nakao K, Uchimura A, Yagi T (2009) Total expression and dual gene-regulatory mechanisms maintained in deletions and duplications of the Pcdha cluster. J Biol Chem 284:32002-32014. CrossRef Medline

O’Driscoll M, Cerosaletti KM, Girard PM, Dai Y, Stumm M, Kysela B, Hirsch B, Gennery A, Palmer SE, Seidel J, Gatti RA, Varon R, Oettinger MA, Neitzel H, Jeggo PA, Concannon P (2001) DNA ligase IV mutations identified in patients exhibiting developmental delay and immunodeficiency. Mol Cell 8:1175-1185. CrossRef Medline

O'Keefe RT, Henderson SC, Spector DL (1992) Dynamic organization of DNA replication in mammalian cell nuclei: spatially and temporally defined replication of chromosome-specific alpha-satellite DNA sequences. J Cell Biol 116:1095-1110. CrossRef Medline

Pascucci B, Russo MT, Crescenzi M, Bignami M, Dogliotti E (2005) The accumulation of MMS-induced single strand breaks in $G_{1}$ phase is recombinogenic in DNA polymerase beta defective mammalian cells. Nucleic Acids Res 33:280-288. CrossRef Medline

Poduri A, Evrony GD, Cai X, Elhosary PC, Beroukhim R, Lehtinen MK, Hills LB, Heinzen EL, Hill A, Hill RS, Barry BJ, Bourgeois BF, Riviello JJ, Barkovich AJ, Black PM, Ligon KL, Walsh CA (2012) Somatic activation of AKT3 causes hemispheric developmental brain malformations. Neuron 74:41-48. CrossRef Medline

Poduri A, Evrony GD, Cai X, Walsh CA (2013) Somatic mutation, genomic variation, and neurological disease. Science 341:1-8. CrossRef Medline

Rogakou EP, Pilch DR, Orr AH, Ivanova VS, Bonner WM (1998) DNA double-stranded breaks induce histone $\mathrm{H} 2 \mathrm{AX}$ phosphorylation on serine 139. J Biol Chem 273:5858-5868. CrossRef Medline

Rogakou EP, Boon C, Redon C, Bonner WM (1999) Megabase chromatin domains involved in DNA double-strand breaks in vivo. J Cell Biol 146: 905-916. CrossRef Medline

Rosin N, Elcioglu NH, Beleggia F, Isgüven P, Altmuller J, Thiele H, Steindl K, 
Joset P, Rauch A, Nürnberg P, Wollnik B, Yigit G (2015) Mutations in XRCC4 cause primary microcephaly, short stature and increased genomic instability. Hum Mol Genet 24:3708-3717. CrossRef Medline

Schultz LB, Chehab NH, Malikzay A, Halazonetis TD (2000) p53 binding protein $1(53 \mathrm{BP} 1)$ is an early participant in the cellular response to DNA double-strand breaks. J Cell Biol 151:1381-1390. CrossRef Medline

Senejani AG, Dalal S, Liu Y, Nottoli TP, McGrath JM, Clairmont CS, Sweasy JB (2012) Y265C DNA polymerase beta knockin mice survive past birth and accumulate base excision repair intermediate substrate. Proc Natl Acad Sci U S A 109:6632-6637. CrossRef Medline

Sharma A, Klein SS, Barboza L, Lohdi N, Toth M (2016) Principles governing DNA methylation during neuronal lineage and subtype specification. J Neurosci 36:1711-1722. CrossRef Medline

Shen J, Gilmore EC, Marshall CA, Haddadin M, Reynolds JJ, Eyaid W, Bodell A, Barry B, Gleason D, Allen K, Ganesh VS, Chang BS, Grix A, Hill RS, Topcu M, Caldecott KW, Barkovich AJ, Walsh CA (2010) Mutations in PNKP cause microcephaly, seizures and defects in DNA repair. Nat Genet 42:245-249. CrossRef Medline

Shi SH, Cheng T, Jan LY, Jan YN (2004) APC and GSK-3beta are involved in mPar3 targeting to the nascent axon and establishment of neuronal polarity. Curr Biol 14:2025-2032. CrossRef Medline

Shimada M, Dumitrache LC, Russell HR, McKinnon PJ (2015) Polynucleotide kinase-phosphatase enables neurogenesis via multiple DNA repair pathways to maintain genome stability. EMBO J 34:2465-2480. CrossRef Medline

Sobol RW (2012) Genome instability caused by a germline mutation in the human DNA repair gene POLB. PLoS Genet 8:e1003086. CrossRef Medline

Sobol RW, Horton JK, Kühn R, Gu H, Singhal RK, Prasad R, Rajewsky K, Wilson SH (1996) Requirement of mammalian DNA polymerase-beta in base-excision repair. Nature 379:183-186. CrossRef Medline

Sobol RW, Kartalou M, Almeida KH, Joyce DF, Engelward BP, Horton JK, Prasad R, Samson LD, Wilson SH (2003) Base excision repair intermediates induce p53-independent cytotoxic and genotoxic responses. J Biol Chem 278:39951-39959. CrossRef Medline

Sugo N, Aratani Y, Nagashima Y, Kubota Y, Koyama H (2000) Neonatal lethality with abnormal neurogenesis in mice deficient in DNA polymerase beta. EMBO J 19:1397-1404. CrossRef Medline

Sugo N, Niimi N, Aratani Y, Takiguchi-Hayashi K, Koyama H (2004) p53 deficiency rescues neuronal apoptosis but not differentiation in DNA polymerase beta-deficient mice. Mol Cell Biol 24:9470-9477. CrossRef Medline

Sugo N, Niimi N, Aratani Y, Masutani M, Suzuki H, Koyama H (2007) Decreased PARP-1 levels accelerate embryonic lethality but attenuate neuronal apoptosis in DNA polymerase beta-deficient mice. Biochem Biophys Res Commun 354:656-661. CrossRef Medline
Sykora P, Yang JL, Ferrarelli LK, Tian J, Tadokoro T, Kulkarni A, Weissman L, Keijzers G, Wilson DM 3rd, Mattson MP, Bohr VA (2013) Modulation of DNA base excision repair during neuronal differentiation. Neurobiol Aging 34:1717-1727. CrossRef Medline

Takahashi T, Nowakowski RS, Caviness VS Jr (1995) The cell cycle of the pseudostratified ventricular epithelium of the embryonic murine cerebral wall. J Neurosci 15:6046-6057. Medline

Takashima H, Boerkoel CF, John J, Saifi GM, Salih MA, Armstrong D, Mao Y, Quiocho FA, Roa BB, Nakagawa M, Stockton DW, Lupski JR (2002) Mutation of TDP1, encoding a topoisomerase I-dependent DNA damage repair enzyme, in spinocerebellar ataxia with axonal neuropathy. Nat Genet 32:267-272. CrossRef Medline

Tsukada T, Tomooka Y, Takai S, Ueda Y, Nishikawa S, Yagi T, Tokunaga T, Takeda N, Suda Y, Abe S, Matsuo I, Ikeda Y, Aizawa S (1993) Enhanced proliferative potential in culture of cells from p53-deficient mice. Oncogene 8:3313-3322. Medline

Tyssowski K, Kishi Y, Gotoh Y (2014) Chromatin regulators of neural development. Neuroscience 264:4-16. CrossRef Medline

Weber AR, Krawczyk C, Robertson AB, Kuúnierczyk A, Vågb, CB, Schuermann D, Klungland A, Schär P (2016) Biochemical reconstitution of TET1-TDG-BER-dependent active DNA demethylation reveals a highly coordinated mechanism. Nat Commun 7:10806. CrossRef Medline

Wei W, Englander EW (2008) DNA polymerase beta-catalyzed-PCNA independent long patch base excision repair synthesis: a mechanism for repair of oxidatively damaged DNA ends in post-mitotic brain. J Neurochem 107:734-744. CrossRef Medline

Wheldon LM, Abakir A, Ferjentsik Z, Dudnakova T, Strohbuecker S, Christie D, Dai N, Guan S, Foster JM, Corrêa IR Jr, Loose M, Dixon JE, Sottile V, Johnson AD, Ruzov A (2014) Transient accumulation of 5-carboxylcytosine indicates involvement of active demethylation in lineage specification of neural stem cells. Cell Rep 7:1353-1361. CrossRef Medline

Wilson SH, Sobol RW, Beard WA, Horton JK, Prasad R, Vande Berg BJ (2000) DNA polymerase beta and mammalian base excision repair. Cold Spring Harb Symp Quant Biol 65:143-155. CrossRef Medline

Yang X, Klein R, Tian X, Cheng HT, Kopan R, Shen J (2004) Notch activation induces apoptosis in neural progenitor cells through a p53-dependent pathway. Dev Biol 269:81-94. CrossRef Medline

Zhong Y, Takemoto M, Fukuda T, Hattori Y, Murakami F, Nakajima D, Nakayama M, Yamamoto N (2004) Identification of the genes that are expressed in the upper layers of the neocortex. Cereb Cortex 14:11441152. CrossRef Medline

Zmudzka BZ, Fornace A, Collins J, Wilson SH (1988) Characterization of DNA polymerase beta mRNA: cell-cycle and growth response in cultured human cells. Nucleic Acids Res 16:9587-9596. CrossRef Medline 